\title{
LEGITIMATE INTERESTS IN MULTISTATE PROBLEMS: AS BETWEEN STATE AND FEDERAL LAW
}

\author{
Lea Brilmayer*†
}

The Supreme Court's renewed interest in multistate problems is striking. ${ }^{1}$ After years of neglect, the Court in the last few terms has decided a series of cases on personal jurisdiction, ${ }^{2}$ choice of law, ${ }^{3}$ and credit to judgments. ${ }^{4}$ Several of these opinions have been pathbreaking; at least one has revolutionized its field. ${ }^{5}$ One of the most recent, Allstate Insurance Co. v. Hague ${ }^{6}{ }^{6}$ is a choice-of-law decision destined to provoke much scholarly comment. ${ }^{7}$

While the case was still pending, one commentator expressed hope that Hague would provide a "coherent" constitutional choiceof-law test to replace the "confused theory of the past." Instead

* Assistant Professor of Law, University of Chicago Law School. B.A. 1970, J.D. 1976, University of California at Berkeley; LL.M. 1978, Columbia University. — Ed.

$\dagger$ A preliminary draft of this paper was presented at The University of Pennsylvania Law School in November 1980 . The author wishes to thank many colleagues who have contributed ideas and criticisms. The consistently fine research assistance of Brenda Lyons, Class of 1981, was supported through the generosity of the Illinois Bar Foundation.

1. In addition to the cases recently decided, see notes 2-4 infra, the Supreme Court has agreed to hear several cases with multistate implications in the 1981-1982 term. See Underwriters Natl. Assurance Co. v. North Carolina Life \& Accident \& Health Ins. Guar. Assn., cert. granted, 101 S. Ct. 2312 (1981) (No. 80-1496) (effect of decision of bankruptcy rehabilitation court when decisions affect rights of citizens of other states); Piper Aircraft Co. v. Reyno, cert. granted, 101 S. Ct. 1346 (1981) (No. 80-848) (relationship between forum non conveniens dismissal and choice of law).

2. See Rush v. Savchuk, 444 U.S. 320 (1980); World-Wide Volkswagen Corp. v. Woodson, 444 U.S. 286 (1980); Kulko v. Superior Court, 436 U.S. 84 (1978); Shaffer v. Heitner, 433 U.S. 186 (1977).

3. See Allstate Ins. Co. v. Hague, 101 S. Ct. 633 (1981); Nevada v. Hall, 440 U.S. 410 (1979).

4. See Thomas v. Washington Gas Light Co., 448 U.S. 261 (1980).

5. Shaffer v. Heitner, 433 U.S. 186 (1977). For discussions of the impact of Shaffer, see Silberman, Shaffer v. Heitner: The End of an Era, 53 N.Y.U.L. REv. 33 (1978); Symposium on Shaffer v. Heitner, 45 Brooklyn L. Rev. 493 (1979); Symposium: State-Court Judicial Jurisdiction After Shaffer v. Heitner, 63 Iowa L. Rev. 991 (1978); Symposium: The Impact of Shaffer v. Heitner, 1978 WASH. U.L.Q. 273.

6. 101 S. Ct. 633 (1981) (plurality opinion).

7. Even before the Supreme Court decided the case, one commentator had discussed the problems resulting from the lower court's opinion and urged reversal. Martin, Personal Jurisdiction and Choice of Law, 78 MICH. L. REV. 872, 886-88 (1980). See Lowenfeld \& Silberman, Choice of Law and the Supreme Court: A Dialogue Inspired by Allstate v. Hague, -U. CAL. D.L. REV. - (1981) (forthcoming).

8. Martin, supra note 7, at 888 . 
Hague has perpetuated, or possibly intensified, the confusion and uncertainty that have characterized constitutional choice-of-law theory. Hague produced three opinions, none of which commanded majority support. Although the plurality and the dissent seemed at times to agree on general principles, those principles were sufficiently vague to support their opposite conclusions. The common ground was that constitutional limits depend in some way on state policy interests, and on the contacts between the dispute and the forum.

This Article examines that common ground, analyzing the roles of state policy interests and contacts in defining constitutional limits. ${ }^{9}$ It concentrates particularly on one paradoxical aspect of the interaction between federal and state law. While the scope of constitutional limits on application of forum law is necessarily a federal issue, constitutional analysis simultaneously defers in some unspecified way to state policy. This is because federal choice-of-law questions frequently turn on the existence of a state policy interest that legitimizes the application of state law. ${ }^{10}$ The resulting interde-

9. This Article discusses only the constitutional limits designed to prevent a state from "overreaching" its constitutionally permissible legislative jurisdiction. It does not address the problem of "underreaching" - the extent to which a state can choose not to apply its law.

One of the critical issues in "underreaching" cases is the extent to which states may decline to extend the protection of their laws to individuals from other states. The pertinent constitutional provisions are the privileges and immunities clause and the equal protection clause. See, e.g., Hicklin v. Orbeck, 437 U.S. 518 (1978); Blake v. McClung, 172 U.S. 239 (1898). Several worthwhile articles discuss this problem. E.g., Simson, Discrimination Against Nonresidents and the Privileges and Immunities Clause of Article IV, 128 U. PA. L. REv. 379 (1979); Note, Unconstitutional Discrimination in Choice of Law, 77 ColuM. L. REv. 272 (1977). See generally J. ELY, DEMOCRACY AND DisTRUST 83 (1980).

One problem with residency distinctions that has not been discussed is that where there are no other multistate elements in the case, states ordinarily do not decline to apply their law merely because of residency. There is a peculiar double standard; although a state may claim in a conflicts case that the nonresidency of the protected party defeats an "interest," where all of the events occurred in the state, it does not even discuss the effect of that party's nonresident status. This assertion can be documented by comparing explicit choice-of-law decisions with diversity cases removed to federal court, where the defendant is by definition a nonresident. See, e.g., Wargo v. Marston, 465 F.2d 1402 (10th Cir. 1972); Davis v. Klaiber, 229 F.2d 883 (6th Cir. 1956); Ortman v. Smith, 198 F.2d 123 (8th Cir.), cert. denied, 344 U.S. 856 (1952) (guest statute cases in which the defendant's nonresidency did not raise choice-of-law problems).

There are, therefore, two problems with using residency distinctions besides the discrimination objection. First, why is it that courts do not routinely treat diversity cases as choice-of-law cases? See, e.g., Sidle v. Majors, 536 F.2d 1156 (7th Cir.), cert. denied, 429 U.S. 945 (1976); Mascarenas v. Johnson, 280 F.2d 49 (5th Cir. 1960); Hess v. Bennett, 245 F.2d 807 (9th Cir. 1957); Von Lackum v. Allan, 219 F.2d 937 (10th Cir. 1955); Peterson v. Denevan, 177 F.2d 411 (8th Cir. 1949); Harlow v. Ryland, 172 F.2d 784 (8th Cir. 1949); Crowell v. M. R. \& R. Trucking Co., 157 F.2d 963 (5th Cir. 1946); Russell v. Turner, 148 F.2d 562 (8th Cir. 1945); Hansen v. Schott, 283 F. Supp. 533 (N.D. Ind. 1967) (guest statute cases in which the state would have had an "interest," but where there should at least have been some choice-of-law discussion).

The second problem is deciding what additional traditional territorial factors must have been contacts with other states before nonresidency becomes significant.

10. Virtually all modern choice-of-law cases frame the due process and full faith and credit issues in terms of state "interests." See, e.g., Nevada v. Hall, 440 U.S. 410, 424 (1979); Carroll 
pendence of the federal and state issues would seemingly empower state legislatures and courts to foreclose constitutional claims through question-begging definitions of the reach of state policies. Only careful definition of the respective roles of state and federal law can prevent the federal issue from completely degenerating into state common law or statutory interpretation.

The first step in defining their respective roles is to distinguish a state's ordinary domestic policies from the policies that it has formulated to deal with multistate problems. Although the constitutional inquiry should take account of the former, it should disregard the latter. Otherwise, these multistate policies will reduce the constitutional issue to a question of state law - what did the state legislature intend? By drafting permissive choice-of-law provisions or expansively interpreting a statute's intended reach, states could control the constitutional outcome.

The second step is to explain how domestic policies enter into the constitutional analysis. Although rather murky, the formulations of the Hague dissent and plurality offer some support for a test based upon state sovereignty. Under this test, a contact connecting the dispute to the forum creates a legitimate interest in applying the forum rule only if there is a regulatory connection between the rule and the contact. The rule must, in other words, be designed to prescribe the legal consequences of the in-state occurrence. But even this formulation endangers the federal issue. Whether a domestic regulatory connection exists depends on how courts construe the rule's underlying policies - an issue of state law. This affords state courts an opportunity to disguise and legitimize their multistate preferences by discerning novel domestic regulatory connections. The solution offered here is a requirement of proof that the regulatory justifications advanced for choice-of-law purposes also serve domestic functions. Throughout the Article, the vehicle for illustrating these arguments is Allstate Insurance Co. v. Hague.

v. Lanza, 349 U.S. 408 (1955); Watson v. Employers Liab. Assurance Corp., 348 U.S. 66 (1954); Pacific Employers Ins. Co. v. Industrial Accident Commn., 306 U.S. 493 (1939); Alaska Packers Assn. v. Industrial Accident Commn., 294 U.S. 532 (1935). All of the opinions in Allstate Ins. Co. v. Hague spoke of "interests." See, e.g., 101 S. Ct. at 637-38 (contacts must create state interests); $101 \mathrm{~S}$. Ct. at $643-44$ (wife's residence and appointment as personal representative in Minnesota demonstrates Minnesota interest); $101 \mathrm{~S}$. Ct. at 645-46 (Stevens, J., concurring) (discussing role of interests under the full faith and credit clause); $101 \mathrm{~S}$. Ct. at 652 (Powell, J., dissenting) (citing B. CURRIE, The Constitution and the Choice of Law: Government Interest and the Judicial Function, in SELECTED ESSAYS ON THE CONFLICT OF LAWS 188 (1963) [entire volume hereinafter cited as B. CuRriE]). 


\section{The Constitutional Irrelevance of Multistate Policies}

In Allstate Insurance Co. v. Hague, the plaintiff's husband, Ralph Hague, had died in a collision with an automobile while riding as a passenger on his son's motorcycle. Neither vehicle operator was insured. The plaintiff brought suit in Minnesota on behalf of her husband's estate, seeking recovery under the uninsured motorist clause in his insurance contract. Although Wisconsin law apparently ${ }^{11}$ would have limited recovery to $\$ 15,000,{ }^{12}$ Minnesota permitted an insured to "stack" insurance. The estate would thus recover $\$ 45,000$ because the deceased's three automobiles each carried $\$ 15,000$ in uninsured motorist coverage.

The defendant, Allstate Insurance Company, argued for application of Wisconsin law. Several contacts supported its position: Allstate had delivered the insurance policy in Wisconsin, the accident had occurred in Wisconsin, and all persons involved were Wisconsin residents at the time of the accident. The trial court nevertheless applied Minnesota law, the Minnesota Supreme Court affirmed,13 and the United States Supreme Court affirmed in turn.

The Hague plurality maintained that a "significant aggregation"14 of three contacts gave Minnesota a constitutionally sufficient interest in applying its stacking rule. First, the plaintiff had become a Minnesota resident after the accident, but before instituting the litigation ${ }^{15}$ - a factor that the plurality explained would be insufficient by itself. ${ }^{16}$ Allstate's continuous business presence in Minnesota

11. The Minnesota Supreme Court found that Wisconsin law was not clear on this issue. Hague v. Allstate Ins. Co., 289 N.W.2d 43, 48 \& n.8, 49 \& n.9 (Minn. 1978), affd. after rehearing en banc, 289 N.W.2d 50 (1979), affd, 101 S. Ct. 633 (1981).

12. Wisconsin law honored "excess insurance" clauses that prohibit the stacking of insurance policies. Although Justice Stevens's concurring opinion assumed that Hague's insurance policies did not prohibit stacking, the Minnesota court thought otherwise, and cast the issue as whether these provisions should be overridden. See Hague v. Allstate Ins. Co., 289 N.W.2d 43, 48 (Minn. 1978), affd. after rehearing en banc, 289 N.W.2d 50 (1979), affd., 101 S. Ct. 633 (1981).

13. Hague v. Allstate Ins. Co., 289 N.W.2d 43 (Minn. 1978), affd. after rehearing en banc, 289 N.W.2d 50 (1979), affd, 101 S. Ct. 633 (1981).

14. $101 \mathrm{~S}$. Ct. at 644.

15. $101 \mathrm{~S}$. Ct. at 643.

16. 101 S. Ct. at 643 (citing John Hancock Mut. Life Ins. Co. v. Yates, 299 U.S. 178 (1936)). By stating that after-acquired domicile would not be sufficient, the plurality probably intended to remove the incentive to forum shop. The plurality also stressed that the change in residence was bona fide. $101 \mathrm{~S}$. Ct. at 643 n.28. Even with these safeguards, however, there still exists a significant incentive to forum shop. First, where a party has other in-state contacts (as in Hague) the possibility that a change in residence may tip the balance could induce the party to move. Second, the state trial court generally will be disposed to find that the move was genuine and the Supreme Court may have a fairly limited power to review this finding of fact. $C f$. Fiske v. Kansas, 274 U.S. 380, 385-86 (1927) (Court limited its review of state court findings of fact to cases where a federal right had been denied as the result of a finding of fact 
supplied a second contact. 17 But the plurality was apparently most impressed with the third contact — Ralph Hague's status as a Minnesota employee at the time of his death. ${ }^{18}$

Each of these contacts raises tantalizing constitutional issues. First, there are good reasons for reluctance to allow a plaintiff's after-acquired domicile to affect the choice of law. Permitting a party to choose a state's law by changing domicile harks back to pre-Erie Railroad $^{19}$ days, when an enterprise could create diversity jurisdiction and avail itself of the federal version of common law by dissolving and reincorporating in another state. ${ }^{20}$ On the other hand, it can be argued that if a state deliberately denies the benefit of forum law to remove incentives to relocate, it may run afoul of the constitutional "right to travel." Although Shapiro v. Thompson"21 is distinguishable, 22 the "right to travel" that Shapiro recognized remains problematic in after-acquired domicile cases. ${ }^{23}$

Allstate's continuous in-state presence and substantial volume of Minnesota business are equally problematic. It is not clear whether this apparently unrelated contact should be held to support the right to apply Minnesota law to this particular case. ${ }^{24}$ Contacts of this

without evidence to support it, or where conclusions of law and fact were too closely intertwined).

17. $101 \mathrm{~S}$. Ct. at $642-43$.

18. $101 \mathrm{~S} . \mathrm{Ct}$. at 640 . As a related and subsidiary aspect of this "very important contact," the plurality pointed out that Hague commuted daily to work in Minnesota. The fact that he was not killed while commuting to work was considered unimportant. $101 \mathrm{~S}$. Ct. at 641 .

19. Erie R.R. Co. v. Tompkins, 304 U.S. 64 (1938).

20. See, e.g., Black \& White Taxicab \& Transfer Co. v. Brown \& Yellow Taxicab \& Transfer Co., 276 U.S. 518 (1928).

21. 394 U.S. 618 (1969).

22. First, the defendant in Hague was a private party; in Shapiro the defendant was a state that had denied public assistance. Second, in Hague, only the amount of recovery was at stake; in Shapiro, the question was whether the plaintiff could recover at all. Third, in Hague the claim was based on past events; in Shapiro the claim was based on present need. But $c f$. Califano v. Torres, 435 U.S. 1 (1978) (loss of social security benefits following move to Puerto Rico did not infringe on right to travel).

23. First, the fact that the defendant was a private individual seems to have no relationship to the right to travel. Second, under Shapiro the state probably could not even limit welfare benefits to the first state's lower award. This would still be an attempt to discourage relocation to achieve higher benefits. Furthermore, Shapiro found objectionable the different treatment of new and old residents.

Third, and most important, Hague relied upon the state's interest in providing recovery for needy plaintiffs. The Court explicitly analogized to state services, as did interest analyst theorists. It is this analogy that makes the "right to travel" argument - which otherwise seems frivolous - colorable and bothersome. See Brilmayer, Interest Analysis and the Myth of Legislative Intent, 78 Mich. L. REv. 392, 411 n.68 (1980).

24. See Allstate Ins. Co. v. Hague, 101 S. Ct. 633, 653 (1981) (Powell, J., dissenting) ("The forum State has no interest in regulating that conduct of the insurer unrelated to property, persons or contracts executed within the forum State.").

The plurality suggested that because Allstate was doing business in Minnesota it would be 
type give rise to general jurisdiction to adjudicate, ${ }^{25}$ but the Court on several occasions has distinguished between adjudicative and legislative jurisdiction. ${ }^{26}$ Reliance upon this contact is tantamount to suggesting that the state has plenary power to regulate conduct occurring anywhere, so long as the burdened party has the sort of continuous contacts that support general adjudicative jurisdiction. To do business in Minnesota, Allstate in effect would have to agree to application of Minnesota law in all of its out-of-state contractual activities. The case support for this proposition is at best ambiguous. ${ }^{27}$

The constitutional doubts surrounding these two contacts make the plurality's emphasis on the third contact especially crucial. Ralph Hague's Minnesota employment is, in any event, the most interesting contact for purposes of analyzing the concept of "legitimate

familiar with Minnesota law. Since Allstate could expect to be sued in Minnesota, it should also anticipate that a Minnesota court would apply its own law. $101 \mathrm{~S}$. Ct. at 642-43. As the dissent argued, this argument proves too much, since it would justify application of the law of any of the fifty states. See 101 S. Ct. at 653 (Powell, J., dissenting). As Justice Powell pointed out, the plurality also failed in its attempt to make the doing business contact relevant by combining it with other contacts. Because the Court did not initially explain the constitutional relevance of doing unrelated business, it is not clear how this contact could add anything to the other contacts. $101 \mathrm{~S}$. Ct. at 653. Furthermore, although Allstate might have expected that Minnesota would try to apply its law, it is circular to suggest that it was obliged for this reason to anticipate that the Supreme Court would allow Minnesota to apply its law.

25. See Allstate Ins. Co. v. Hague, 101 S. Ct. at 653 n.4 (Powell, J., dissenting).

26. See, e.g., Allstate Ins. Co. v. Hague, 101 S. Ct. at $644-45$ (Stevens, J., concurring); Kulko v. Superior Court, 436 U.S. 84, 98 (1978); Shaffer v. Heitner, 433 U.S. 186, 215 (1977); Hanson v. Denckla, 357 U.S. 235, 254 (1958). See generally Martin, supra note 7.

27. Compare Skiriotes v. Florida, 313 U.S. 69 (1941) (state may apply criminal law to resident engaged in prohibited activity outside Florida territorial waters), with Bigelow v. Virginia, 421 U.S. 809, 824 (1975) (dictum suggesting that Virginia might not punish its citizens for obtaining abortion in New York). Where the conduct did not occur in another state, as in Skiriotes, the constitutional considerations are different because of the wording of the full faith and credit clause. See Martin, Constitutional Limitations on Choice of Law, 61 CoRNell L. REV. 185 (1976).

Federal regulatory statutes have also been given extraterritorial effect. See Blackmer v. United States, 284 U.S. 421 (1932) (subpoena power over United States citizens extends to foreign countries); United States v. Bowman, 260 U.S. 94 (1922) (citizens committing acts in a foreign country directly injurious to the United States government are subject to punishment under $\S 35$ of the Criminal Code); Bryant v. International Schools Servs., Inc., 502 F. Supp. 472 (D.N.J. 1980) (Title VII of the Civil Rights Act of 1964 extends to an American corporation's employment practices in a foreign country).

The decision to give a federal statute extraterritorial effect has been approached as a matter of statutory interpretation. See Bryant v. International Schools Servs., Inc., 502 F. Supp. 472, 482 (D.N.J. 1980). Several cases dealing with the reach of various labor laws have taken this approach to preclude extraterritorial application of these statutes. See McCulloch v. Sociedad Nacional, 372 U.S. 10 (1963); Benz v. Compania Naviera Hidalgo, S.A., 353 U.S. 138 (1957); Foley Bros., Inc. v. Filardo, 336 U.S. 281 (1949); GTE Automatic Elec., Inc., 226 N.L.R.B. 1222 (1976); RCA OMS, Inc., 202 N.L.R.B. 228 (1973). The federal right to regulate extraterritorial conduct is stronger than the state's right to regulate activity in other states because it is not constrained by the full faith and credit clause. None of these cases, however, adequately analyzed Congress's power to exercise extraterritorial jurisdiction in the first instance. 
interests." The Hague plurality concluded that Minnesota employment contributed to Minnesota's legitimate interest in applying its stacking rule because Minnesota had police power responsibilities toward persons employed there. ${ }^{28}$ Although the dissent also framed the problem in terms of interests, ${ }^{29}$ it suggested that employment was an inadequate contact because it was irrelevant to the legal issue. ${ }^{30}$ Neither opinion took advantage of the opportunity to formulate general guidelines for determining whether contacts give rise to "legitimate interests." This challenge posed by the third contact is central to any policy-based analysis.

The only existing methodological formulation for evaluating state interests is demonstrably incomplete. Brainerd Currie, ${ }^{31}$ the leading academic proponent of interest analysis, explained: "The method I advocate is the method of statutory construction. . . . It is explicitly an attempt to determine legislative purpose."32 This explanation has the advantage of making the policies behind the competing rules relevant to the constitutional inquiry. Prior choice-of-law methods had merely characterized a problem as tort or contract, and then proceeded mechanically to apply the "place of wrong" or "place of making" rule. ${ }^{33}$ But while superior in some respects to the primitive methods that most courts had been using, Currie's system has the unattractive side effect of reducing all constitutional choiceof-law issues to questions of state statutory interpretation. ${ }^{34}$

28. $101 \mathrm{~S}$. Ct. at 640.

29. $101 \mathrm{~S}$. Ct. at $651-52$.

30. 101 S. Ct. at 654.

31. See, e.g., B. CURRIE, supra note 10.

32. B. Currie, Conficts, Crisis, and Confusion in New York, supra note 10, at 690, 727.

33. See Restatement (First) of Conflict of Laws $\$ \S 332,337$ (1934).

34. See Brilmayer, supra note 23, at 401 . Currie of course realized that there were limits on what states might do through assertion of an "interest." At one point he suggested that the Supreme Court must ask whether the policy has a "demonstrable existence," or whether it is "too technical or attentuated to be of constitutional significance." B. CURRIE, supra note 10, at 277. He never explained how to reconcile this with the principle of statutory construction, or with his vehement insistence that the Court should not "label one interest paramount and the other minimal." Id.

His discussion of Clay v. Sun Ins. Office Ltd., 363 U.S. 207 (1960), is equally confusing. B. CURrIE, The Verdict of Quiescent Years, supra note 10, at 584, 625. He assumed that "essentially, the inquiry is whether that court would construe the statute as applicable to a case of the Clay type." He then argued that if the state court stated on remand that it would do so, the Court should ask whether an essentially retroactive application was consistent with the due process and contracts clauses. This is quite astounding given his characteristic disparagement of predictability and vested rights arguments. See Brilmayer, supra note 23, at 399 n.34. Moreover, since the contracts clause and retroactivity prohibitions do not apply to judicial decision making, there would be no limitation whatsoever where the underlying rule was supplied by common law. For a discussion of the different predictability constraints imposed on legislatures and courts, see Brilmayer, The Institutional and Empirical Bases of the Rights Thesis, 11 GA. L. REV. 1173, 1178 (1977). 
The problem is most obvious when the state has an explicit statutory choice-of-law rule, as in the early case of Alaska Packers Association v. Industrial Accident Commission. ${ }^{35}$ In such circumstances, a definition of "interest" that turns upon statutory interpretation is satisfied whenever the state choice-of-law provision purports to make the statute applicable. Even where the state has no explicit choiceof-law provision, however, the identical problem arises: a state court could create interests by expansively interpreting a statute's intended territorial reach. From the federal perspective, an explicit state court interpretation should be as authoritative as an explicit statutory choice-of-law provision. ${ }^{36}$ In fact, when a state court construes state law, there is not even a jurisdictional basis for appeal to the Supreme Court. ${ }^{37}$ Thus in Hague, for instance, the statute could be definitively "construed" as applicable whenever the deceased was employed in the state, with no basis for federal scrutiny. If "policy analysis" is taken literally and without qualification, it gives state legislatures and courts effective authority to decide that a constitutionally sufficient interest exists.

Adherence to the familiar distinction between state "internal" law and state "whole" law obviates the problem. ${ }^{38}$ A state's internal law consists of its domestic rules and policies; whole law includes both internal law and the state's conflict-of-law policies. When determining the existence of a legitimate interest, courts should consider a state's internal domestic policies, but not its multistate choiceof-law policies.

Two analogous uses of the interest terminology give rise to strikingly similar problems, and thus demonstrate the usefulness of this distinction. First, a number of personal jurisdiction cases have relied upon the concept of a state interest in providing a forum. ${ }^{39}$ In Shaffer $v$. Heitner, ${ }^{40}$ for example, the plaintiff argued that Delaware had

35. 294 U.S. 532 (1935). See Pacific Employers Ins. Co. v. Industrial Accident Commn., 306 U.S. 493 (1939).

36. Erie R.R. Co. v. Tompkins, 304 U.S. 64 (1938), for example, held that state decisional law was entitled to the same recognition as state statutory law. Even prior to Erie, however, federal courts followed state court interpretations of state statutes.

37. For an important qualification, see Part II, § C infra.

38. See, e.g., R. CRAMTON, D. CURRIE \& H. KAY, CoNfLICT OF LAws 68 (2d ed. 1975); R. Weintraub, Commentary on the Conflict of Laws 67-71 (2d ed. 1980) (discussing renvoi).

39. See Kulko v. Superior Court, 436 U.S. 84, 98 (1978); McGee v. International Life Ins. Co., 355 U.S. 220, 223 (1957). On the role of state interests in the law of personal jurisdiction, see generally Brilmayer, How Contacts Count, 1980 SUP. CT. REv. 77; Carrington \& Martin, Substantive Interests and the Jurisdiction of State Courts, 66 MicH. L. REv. 277 (1967).

40. 433 U.S. 186 (1977). 
a strong interest in entertaining shareholder derivative suits against managers of Delaware corporations. The court rejected this argument, reasoning that if such an interest had existed, Delaware would have expressed it in a specifically drawn jurisdictional statute addressing derivative suits against Delaware corporations:

[The] argument is undercut by the failure of the Delaware Legislature to assert the state interest appellee finds so compelling. Delaware law bases jurisdiction, not on appellants' status as corporate fiduciaries, but rather on the presence of their property in the State. ${ }^{41}$

If the Court's rationale was that explicit expression of a specific interest would meet constitutional objections, then states could draft away their constitutional problems by making their jurisdictional statutes more specific. ${ }^{42}$ In a separate opinion, Justice Brennan understandably was troubled by letting the constitutional issues depend so directly on state law. He could not "understand how the existence of minimum contacts in a constitutional sense is at all affected by Delaware's failure statutorily to express an interest in controlling corporate fiduciaries." 43

Recognition-to-judgments cases present analogous problems. In Thomas v. Washington Gas Light Co., ${ }^{44}$ decided last term, a plurality of the Court echoed Justice Brennan's Shaffer concerns and refused to make a state's multistate policies constitutionally dispositive. Thomas was a workmen's compensation case that reexamined the so-called "Magnolia/McCartin test." 45 Under that test, one state's workmen's compensation award barred a subsequent award in another state only if "unmistakable language" in the first state's statute precluded awards in other states. Prior case law indicated that the full faith and credit clause and its implementing statute compelled the test. ${ }^{46}$ But the plurality found it peculiar that the full faith and credit issues should turn upon the interpretation of state statutes. It observed that automatically deferring to the first state's statute "authorizes a State, by drafting or construing its legislation . . . directly to determine the extraterritorial effect of its workmen's compensa-

41. 433 U.S. at 214.

42. Several lower court cases have upheld jurisdiction under similar circumstances on the basis of a more specifically drafted statute. See, e.g., Armstrong v. Pomeranz, 423 A.2d 174 (Del. 1980); Swenson v. Thibaut, 39 N.C. App. 77, 250 S.E.2d 279 (1978), appeal dismissed, 296 N.C. 740,254 S.E.2d 181 (1979).

43. 433 U.S. at 226.

44. 448 U.S. 261 (1980) (plurality opinion).

45. The Magnolia/McCartin test is derived from Magnolia Petroleum Co. v. Hunt, 320 U.S. 430 (1943), and Industrial Commn. v. McCartin, 330 U.S. 622 (1947).

46. 28 U.S.C. § 1738 (1976). 
tion awards." 47 The plurality fiatly refused to permit states to dictate the constitutional outcome through careful drafting or interpretation of its statutes: "[The Magnolia/McCartin test] represents an unwarranted delegation to the States of this Court's responsibility for the final arbitration of full faith and credit questions." 48

In both personal jurisdiction and recognition-to-judgments cases, differentiation between domestic and multistate policies achieves the best of both worlds. Courts can defer to state domestic policy concerns without allowing states the latitude to dispose of federal issues. Multistate preferences, such as a naked desire to provide a forum, should not support a determination that interests sufficient to uphold personal jurisdiction exist. ${ }^{49}$ Yet the due process limits indirectly reflect state domestic interests. The substantive rules that govern the litigation determine which contacts are specifically related to the dispute, and contacts so related have greater justificatory force..$^{50}$ Similarly, in credit-to-judgments cases, courts should defer to the rendering state's domestic res judicata policies. ${ }^{51}$ They should not, however, permit a state directly to dictate the preclusive effect of its judgments in other states. 52

47. 448 U.S. at 270.

48. 448 U.S. at 271 (footnote omitted).

49. Cf. Carrington \& Martin, supra note 39, at 237 (presumption of validity does not attach to state jurisdictional policies).

50. See Brilmayer, supra note 39.

51. One casebook, for example, treats the issues raised by 28 U.S.C. $\S 1738$ (1976) as a problem of federal incorporation of state res judicata law. P. BATOR, P. MISHKIN, D. SHAPIRO \& H. WeChSler, Hart \& Weschsler's The Federal Courts and the Federal System 505 (2d ed. 1973). See Adam v. Saenger, 303 U.S. 59, 64 (1938).

52. See Thomas v. Washington Gas Light Co., 448 U.S. at 270:

[B]y virtue of the full faith and credit obligations of the several States, a State is permitted to determine the extraterritorial effect of its judgments; but it may only do so indirectly, by prescribing the effect of its judgments within the State.

The McCartin rule, however, focusing as it does on the extraterritorial intent of the rendering State, is fundamentally different. It authorizes a State, by drafting or construing its legislation in "unmistakable language," directly to determine the extraterritorial effect of its workmen's compensation awards.

Justice Stevens was undoubtedly right in principle: a state should not have complete authority to determine the res judicata effect of its judgments in other states. For instance, the second forum should not be bound to honor the first state's res judicata policies if the first state's policies explicitly give greater res judicata effect to its judgments when enforced in another state. But Justice Stevens misapplied this principle to the facts of Thomas, because he disregarded a valid internal law policy - releasing the insurer from further liability of any kind. Justice Stevens declared that this interest was "not of controlling importance," 448 U.S. at 280 , because the worker could have filed initially in the more generous state.

This reasoning is completely unsatisfactory. In every full faith and credit case that seeks a second judgment, the plaintiff could have filed initially in the second state. If taken seriously, this argument would totally destroy all credit-to-judgments requirements - the second state would never be constitutionally obliged to honor the first state's more restrictive internal res judicata policies. Justice Stevens's argument is a blanket criticism of res judicata policies, whether domestic or multistate. A defendant should not lose his plea of res judicata if it ap- 
As Justice Brennan's Shaffer and the Thomas plurality opinions indicate, it is not consonant with the purposes of constitutional adjudication to give constitutional weight to a state's multistate policies. Many values are constitutionally protected precisely because they are more important to the federal enterprise than to the states. States are likely to be insufficiently solicitous of or even hostile to such values. The "free trade" ideal embodied in the commerce clause is illustrative. When enacting protectionist laws, a state considers only its own immediate gains and losses and may underestimate the resultant harm to the federal system. For this reason, the Court does not defer to a state's protectionist policies, 53 but considers only concededly legitimate goals, such as safety and health.

As in commerce clause cases, constitutional limits regarding credit to judgments, jurisdiction, and choice of law exist because states are likely to be insufficiently sensitive to the needs of the federal system. It would thus be inconsistent with these limitations to give states effective authority to decide their scope. Peculiarly multistate policies are suspect in ways that domestic policies are not, for the political safeguards accompanying adoption of domestic rules are absent. ${ }^{54} \mathrm{~A}$ state presumably formulates its internal law after

pears that, had the plaintif handled the case more competently, the result would have been different. In the adversary system, parties are bound by their mistakes, including presumably a foolish choice of forum. Furthermore, Justice Stevens's reasoning would allow a plaintiff deliberately to file first in a state with lenient substantive rules and then in a state with restrictive substantive rules but higher monetary awards, without jeopardizing his initial recovery.

Although constitutionally irrelevant, extraterritorial intent may be given effect regarding a question of state law: does the state intend to exercise less than its constitutional share of power? Perhaps the $M c$ Cartin rule can be justified as addressing this state law issue. The first state has the constitutional authority to preclude an award in the second state, but the first state may not wish to exercise its preclusive power. The McCartin rule can be interpreted as an attempt to answer this question by looking at the language in the first state's statute. The Court reviews this state law issue only because it must review the second forum's interpretation of the first state's law. See P. BATOR, P. Miskin, D. Shapiro \& H. WechSLER, supra note 51, at 505 . This basis for Supreme Court review is absent when a state deliberately restricts its adjudicative or legislative jurisdiction.

53. See, e.g., Philadelphia v. New Jersey, 437 U.S. 617, 624 (1978) ("The crucial inquiry, therefore, must be directed to determining whether [the regulation] is basically a protectionist measure, or whether it can fairly be viewed as a law directed to legitimate local concerns, with effects upon interstate commerce that are only incidental."); South Carolina State Highway Dept. v. Barnwell Bros., Inc., 303 U.S. 177, 184 n.2 (1938); L. TrIBE, AMERICaN ConstitU- . TIONAL LAW 21-30 (Supp. 1979).

54. Cf. K̇ramer v. Union Free School Dist. No. 15, 395 U.S. 621, 627-28 (1969) (presumption of constitutionality under "rational basis" test is based on assumption that state represents all interests fairly, and does not apply where this assumption cannot be made). One need not envision the Constitution as protecting almost entirely procedural values, see J. ELY, supra note 9 , to recognize the validity of this concern. That the Constitution safeguards values inadequately protected by democratic procedure does not mean that the values in question are themselves procedural. The democratic process may inadequately protect freedom of religion values, and this may be a reason for granting them protection. But freedom of religion may be an end in itself, regardless of whether free exercise promotes democracy. 
careful consideration of all sides of the issue; proponents of each side are represented in the decision-making process. But there are no similar constraints on the formulation of multistate policy. Because a state does not bear the costs of its own overreaching, one state is unlikely to consider adequately the federal interest in protecting the needs of others. Rather, each state is bound to feel that it has chosen the better rule, and will be biased in favor of that rule in multistate cases. 55

The distinction between multistate and domestic policies should be relatively easy to apply because multistate policies are those that refer to state lines. They are relevant only when interstate relations are at issue, and are unnecessary to the disposition of any purely domestic disputes. For instance, a rule invalidating contracts made by married women constitutes a domestic policy choice. A principle that this rule applies to contracts made within the state, or to contracts made by women residing in the state, constitutes a multistate policy choice.

This relatively straightforward distinction is, moreover, implicit in several Supreme Court cases. ${ }^{56}$ Using the interest terminology, both Alaska Packers Association v. Industrial Accident Commission ${ }^{57}$ and Pacific Employers Insurance Co. v. Industrial Accident Commission $^{58}$ upheld the application of California's workmen's compensation statute. The statute's choice-of-law provision unambiguously dictated application of California law. The Court did not dispose of the cases merely by reference to the statutory choice-of-law provisions; rather, it seemed to recognize that purely multistate policies do not count even under a policy-oriented approach. There is even some circumstantial evidence that Brainerd Currie himself might have agreed, if the question were squarely presented, that interests result only from internal law policies. 59

55. One choice-of-law theory, in fact, explicitly requires a court to decide which is the "better law." Leflar, Conficts Law: More on Choice-Infuencing Considerations, $54 \mathrm{CAL} . \mathrm{L}$. REV. 1584 (1966) (listing five factors, one of which is application of the better rule of law). This almost invariably turns out to be the forum's own rule of decision.

56. See Reese \& Johnson, The Scope of Full Faith and Credit to Judgments, 49 ColuM. L. REV. 153, 162 n.49 (1949).

57. 294 U.S. 532 (1935). 03.

58. 306 U.S. 493 (1939). The Court referred explicitly to domestic policy. 306 U.S. at 502-

59. For instance, in deciding whether other states had interests in a case, he analyzed only state internal law. His treatment of renvoi suggests the same conclusion - he tended to disregard other states' choice-of-law rules in defining their interests:

[I] seems clear that the problem of the renvoi would have no place at all in the analysis that has been suggested. Foreign law would be applied only when the court has determined that the foreign state has a legitimate interest in the application of its law and 
This disregard of multistate policies does not mean that states are constitutionally precluded from adopting choice-of-law provisions. Such provisions indicate whether the state wishes to exercise legislative jurisdiction to the extent permitted by the Constitution. 60 Satisfaction of state choice-of-law provisions is a necessary condition to application of the domestic rule, and is an issue of state law. ${ }^{61}$ But

policy to the case at bar and that the forum has none. Hence, there can be no question of applying anything other than the internal law of the foreign state.

B. CURRIE, Notes on Methods and Objectives in the Conflict of Laws, supra note 10, at 177, 184. For other indications, see B. CURRIE, On the Displacement of the Law of the Forum, supra note 10 , at 3, 52 (distinguishing choice-of-law rules from "normal governmental policies"); B. CuRRIE, supra, at 170 (criticizing legislative adoption of choice-of-law rules); B. CURRIE, supra, at 52 ("A choice-of-law rule is an empty and bloodless thing. Actually, instead of declaring an overriding public policy, it proclaims the state's indifference to the result of the litigation.").

60. There are, of course, constitutional limitations on the ways that a state may choose to exercise its jurisdiction. See note 9 supra. In addition, some of the difficulties that arise where the state uses substantively irrelevant variables to extend jurisdiction, see text at note 71 infra, apply in less virulent form where the state restricts its jurisdiction. This can be illustrated by a guest statute example. In conflicts cases, it is sometimes argued that guest statutes are designed to provide recovery for injured third parties, the suggestion being that where there is an out-ofstate third party or no third party at all, there is no interest in applying the guest statute. See, e.g., Dym v. Gordon, 16 N.Y.2d 120, 209 N.E.2d 792, 262 N.Y.S.2d 463 (1965) (Colorado guest statute protects Colorado insurers against fraudulent claims and gives injured third parties priority over ungrateful guests). Yet states do not ordinarily allow the existence of insurance to be raised at trial; it is deliberately made irrelevant, Brilmayer, supra note 23 , at 413 , so that absence of insurance would not defeat a state interest.

Moreover, states with guest statutes never take account of whether there is a third party involved in purely domestic cases. For instance, one guest statute jurisdiction, Michigan, with a policy of priority for third parties, routinely applies its guest statute in domestic cases where no third party was involved, without even discussing whether this poses a statutory construction problem. See, e.g., Brooks v. Haack, 374 Mich. 261, 132 N.W.2d 13 (1965) (auto left straight and level road, traversed shallow ditch, and was demolished upon collision with utility pole); Karney v. Upton, 353 Mich. 262, 91 N.W.2d 297 (1958) (driver hit guardrail on bridge); Estate of Welty v. Estate of Wolfe, 345 Mich. 408, 76 N.W.2d 52 (1956) (wrongful death action against automobile owner's estate; auto left highway, collided with tree, killing owner and passenger); Stolt v. Shalogian, 326 Mich. 435, 40 N.W.2d 212 (1949) (car hit curve and turned over); Butine v. Stevens, 319 Mich. 176, 29 N.W.2d 325 (1947) (car left road and turned over); Bushie v. Johnson, 296 Mich. 8, 295 N.W. 538 (1941) (passenger died when car hit tree); Sherman v. David, 293 Mich. 489, 292 N.W. 464 (1940) (car rolled over; driver had been warned he was traveling too fast and was coming upon a curve); Holmes v. Wesler, $274 \mathrm{Mich} .655,265$ N.W. 492 (1936) (vehicle hit telephone pole).

The same result has been reached in Colorado. See, e.g., Rennels v. Marble Prods., Inc., 175 Colo. 229, 486 P.2d 1058 (1971) (ex-wife (guest) against former husband (driver) and his corporation for injuries sustained when car hit bridge abutment); Loeffler v. Crandall, 129 Colo. 384, 270 P.2d 769 (1954) (Colorado residents returning from trip to Mexico had accident in Colorado; car hit oily part of the road and skidded off).

The reliance upon substantively irrelevant factors thus poses two questions. First, what accounts for the difference in attitude towards the factor in domestic and multistate cases? The answer may be that since there are special reasons for deference in multistate cases, using new variables to restrict jurisdiction is appropriate. Second, what other contacts must point to other states before factors irrelevant in purely domestic controversies are granted significance? Brilmayer, supra note 23, at 413-14.

61. But see note 9 supra. Different issues are involved when the state admittedly has legislative jurisdiction and uses multistate criteria in formulating rules to exercise it. Unless suspect classifications are involved, the state need only show a rational basis for different treatment in the equal protection context. See, e.g., Jones v. Helms, 101 S. Ct. 2434 (1981) (upholding state 
satisfaction of state choice-of-law provisions does not guarantee that the state has met federal constitutional standards. State law is preempted precisely on the issue of whether a constitutionally sufficient interest exists. Unqualified deference to state policy would transform what is obviously a federal issue into an exercise in state statutory construction. When properly circumscribed, however, state domestic policies play an important role in the determination of legitimate interests.

\section{Legitimate Interests, Domestic Policies, AND Multistate Policies In Disguise}

The Hague plurality concluded that a "significant aggregation of contacts . . . , creating interests," 62 justified the application of Minnesota law. Its reliance upon the concept of legitimate interests follows those modern choice-of-law cases ${ }^{63}$ that have suggested that a legitimate interest gives a state at least a prima facie claim to apply its law to a dispute. ${ }^{64}$ Essentially the same formulation is used re-

law providing different penalties for child abandonment totally within the state than for child abandonment followed by departure from the state).

62. $100 \mathrm{~S}$. Ct. at 644 (footnote omitted).

63. See, eg., Nevada v. Hall, 440 U.S. 410, 424 (1979); Carroll v. Lanza, 349 U.S. 408 (1955); Watson v. Employers Liab. Assurance Co., 348 U.S. 66 (1954); Pacific Employers Ins. Co. v. Industrial Accident Commn., 306 U.S. 493 (1939); Alaska Packers Assn. v. Industrial Accident Commn., 294 U.S. 532 (1935).

64. The language of prima facie claims is taken in a somewhat altered form from Alaska Packers Assn. v. Industrial Accident Commn., 294 U.S. 532, 547 (1935) ("Prima facie every state is entitled to enforce in its own courts its own statutes, lawfully enacted."). A prima facie claim will not necessarily put all constitutional objections to rest. Commerce clause cases provide one illustration. The state has a legitimate police power interest in regulating safety equipment on trucks on its highways. Nevertheless, the state's prima facie regulatory claim can be overridden if the state's regulations impose an unreasonable burden on commerce. See Bibb v. Navajo Freight Lines, Inc., 359 U.S. 520 (1959). In the choice-of-law context, a state's prima facie claim might give way for two reasons. First, this Article discusses primarily constitutional choice-of-law limits derived from the constitutional value of state sovereignty. So defined, a legitimate interest might be overridden because other constitutional values such as fairness to litigants are violated.

Second, one state's legitimate interest may in some cases be outweighed by another's. The Court thus balanced the interests of each jurisdiction, deciding which was superior. See Alaska Packers Assn. v. Industrial Accident Commn., 294 U.S. 532, 547-48 (1935) (conflicting interests of foreign state must be shown to be superior to displace law of interested forum). It is now settled that, at least in some instances, several states may have concurrent jurisdiction. Allstate Ins. Co. v. Hague, $101 \mathrm{~S}$. Ct. at 637 (plurality opinion). And the Hague plurality opinion stated that there was no general requirement of balancing interests. $101 \mathrm{~S}$. $\mathrm{Ct}$. at 637 n.10. Although it is thus not clear whether one state's interest could ever outweigh another state's interest, one such situation might be where the state of incorporation forbade cumulative voting but the residence of some shareholders required it. Cf. Order of United Commercial Travelers v. Wolfe, 331 U.S. 586 (1974) (need for uniformity in regulation of fraternal benefit society means that only law of place of incorporation can be applied); MITE Corp. v. Dixon, 633 F.2d 486 (7th Cir. 1980); Western Air Lines, Inc. v. Sobieski, 191 Cal. App.2d 399, 12 Cal. Rptr. 719 (1961) (commerce clause limits on state regulation of tender offers). 
gardless of whether the challenge to application of forum law is based upon article IV's full faith and credit clause ${ }^{65}$ or the due process clause. ${ }^{66}$ Indeed, the Court has never clearly defined the different roles of these two provisions, ${ }^{67}$ but uses them in conjunction to safeguard against unfairness to individuals and lack of respect for other states' laws. The concept of "legitimate interests" is relevant to both constitutional inquiries, ${ }^{68}$ and in translating domestic policies into legitimate interests the key concept is "contacts."

\section{A. Contacts Creating Interests}

A contact is a circumstance - a person, event, or item of property - that connects the controversy with one of the involved states. ${ }^{69}$ The plurality's reference to some aggregations of contacts as being significant suggests that not all in-state contacts support the application of forum law. Presumably the fact that Lavinia Hague's lawyer was licensed to practice in Minnesota would not create a Minnesota interest, even if her lawyer was working for a contingent

65. U.S. CoNST. art. IV, $\S 1$.

66. U.S. Const. amend. XIV, $\S 1$.

67. Sometimes the Court relies on one clause, and sometimes on the other, and sometimes it even seems to be suggesting that the two constraints are identical. See Kirgis, The Roles of Due Process and Full Faith and Credit in Choice of Law, 62 CoRNell L. REv. 94 (1976); Martin, A Reply to Professor Kirgis, 62 CoRnell L. Rev. 151 (1976); Martin, supra note 27. The wording of the full faith and credit clause implies that the clause applies only where the choice is between the laws of two states. Where the competing law is that of another nation, the only restriction is due process. See, e.g., Skiriotes v. Florida, 313 U.S. 69 (1941); Home Ins. Co. v. Dick, 281 U.S. 397 (1930). In other situations, the differences are obscure.

The Hague opinions fared no better than most in untangling the two clauses. See $101 \mathrm{~S}$. Ct. at 637 n.10 (plurality opinion) ("This Court has taken a similar approach in deciding choice-of-law cases under both the Due Process Clause and the Full Faith and Credit Clause. In each instance, the Court has examined the relevant contacts and resulting interests of the State whose law was applied."); $101 \mathrm{~S}$. Ct. at 650 (Powell, J., dissenting). In his concurring opinion, Justice Stevens attempted to distinguish between the two clauses, but his approach was idiosyncratic. See $101 \mathrm{~S}$. Ct. at 644-50 (Stevens, J., concurring). He stated, for example, that he doubted whether a state applying its own law ever violated due process. Because a judge would always be familiar with his own state's law, it could never be irrational to prefer it. $101 \mathrm{~S}$. Ct. at 647 . He concluded only that there might be an arguable due process objection if the rule was surprising or unfair as applied.

68. See note 63 supra. Although an interest is, in general, a necessary condition for the application of forum law, one exception may be where neither state has an interest. In interest analysis terminology, this is the "unprovided for case." See R. CRAMTON, D. CuRrie \& H. KAY, supra note 38, at 275-83. Since this Article's definition of "interest" is considerably less restrictive than Brainerd Currie's, see text at note 127 infra, this situation will arise only infrequently. One such case may be where the second state's choice-of-law rule disclaims a desire to have its law applied.

69. A contact results from the geographic affiliation of a person; event, or item of property with one of the involved states. The word circumstance is here used generally to signify any element of the dispute that comprises a contact. In some cases, a failure to act may constitute a contact. See Brilmayer, supra note 39 , at 90 . Another possible contact with the forum might be the parties' selection of forum law in a contract. 
fee. ${ }^{70}$ The Hague plurality gave scant indication of why it thought that Minnesota employment, in contrast, did.

Criteria for assessing the legitimacy of interests can be derived from constitutional values recognized as important in the choice-oflaw process. Unfair surprise certainly plays a role in shaping constitutional limits, but the concept of state sovereignty or territorial integrity is also important. Each state has a prima facie right to regulate domestic contacts - persons, property, or events affiliated with the state - but a state generally has no business regulating circumstances connected only with other states. The word "regulate" is being used here in a fairly expansive manner, meaning only that the state prescribes the contact's legal significance.

Although circumstances that do not constitute forum contacts are not the proper subject of the state's attention, there are some situations in which a state must be able to prescribe their legal consequences. Legal rules characteristically mandate the legal effect of a conjunction of circumstances that must all be satisfied for the effect to follow. In purely domestic cases, all of the relevant components of the cause of action are, by definition, in-state contacts. When a state applies its law to such cases, it does not intrude upon the sovereignty of other states because it does not prescribe the effects of events that occurred elsewhere. But in multistate cases, the circumstances that the rule governs may be divided among several states. The state whose rule is applied thus unavoidably dictates the legal results of occurrences elsewhere. Yet prescribing the legal significance of out-of-state contacts is presumptively justifiable as a necessary means to a legitimate end - regulation of the in-state contacts.

An in-state contact, therefore, supplies a prima facie justification for the application of forum law when the rule in question is being used to regulate that contact. Application to occurrences elsewhere is incidental to this legitimate end. Absent a regulatory connection between the legal rule and the in-state contact, the rule does not prescribe the consequences of any in-state contact, but merely regulates out-of-state occurrences. To illustrate, suppose that at the time of the accident, Hague had been acting in the course of his employment. If the issue were whether Minnesota or Wisconsin workmen's compensation law applied, then Minnesota employment would surely be a contact that created an interest. ${ }^{71}$ This is true even

70. But see Haag v. Barnes, 9 N.Y.2d 554, 560, 175 N.E.2d 441, 444, 216 N.Y.S.2d 65, 69 (1961) (mentioning Illinois residence of attorneys as relevant contact with Illinois).

71. The plurality's citations to workmen's compensation cases in support of the relevance of Minnesota employment, $101 \mathrm{~S}$. Ct. at 641, are for this reason inapposite. Alaska Packers 
though the end result would be to prescribe the legal consequences of an out-of-state accident. It is impossible to avoid such a result because if Wisconsin workmen's compensation law were applied, this would prescribe the consequences of an employment relationship located in Minnesota.

But if the issue were not which workmen's compensation law to apply, but which state's speed limit, then Minnesota employment would clearly be irrelevant and Wisconsin law should be applied. Minnesota cannot claim to be using its speed limit to regulate Minnesota employment. Workmen's compensation rules regulate working, but traffic rules regulate driving, and the driving in question is not the proper subject of Minnesota's concern because it occurred elsewhere. Hague poses a problem between these two extremes. Whether Minnesota employment creates an interest in applying the insurance stacking rule depends upon whether there is some connection between stacking and employment status such that the rule seems designed to prescribe the legal consequences of Hague's employment.

A forum contact justifies the application of state law on some issues but not on others because some legal rules regulate that contact and some do not. This is the choice-of-law analog of what has been termed "specific jurisdiction" to adjudicate.72 Personal and legislative jurisdiction are not identical, ${ }^{73}$ but in both areas contacts related to the substantive issues in the case have greater significance in constitutional justification. ${ }^{74}$ This explains why a contact can give the forum personal jurisdiction to adjudicate certain claims against the defendant, but not others. ${ }^{75}$ Similarly, for choice-of-law pur-

Assn. v. Industrial Accident Commn., 294 U.S. 532 (1935), and Pacific Employers Ins. Co. v. Industrial Accident Commn., 306 U.S. 493 (1939), were workmen's compensation cases; the fact of employment could hardly be more relevant. In substantive terms, workmen's compensation schemes were obviously designed to regulate the employment relationship. By citing these cases, the plurality carelessly seemed to suggest that a contact significant for some issues would be significant for all.

72. von Mehren \& Trautman, Jurisdiction to Adjudicate: A Suggested Analysis, 79 HARv. L. REV. 1121, 1144-45 (1966).

73. The Court consistently has recognized the analogy, but suggested that there are important differences between the two issues. See, e.g., Allstate Ins. Co. v. Hague, $101 \mathrm{~S}$. Ct. 633, 644 n.3 (Stevens, J., concurring); Kulko v. Superior Court, 436 U.S. 84, 98 (1978); Shaffer v. Heitner, 433 U.S. 186, 216 (1977); Hanson v. Denckla, 357 U.S. 235, 253 (1958). For two discussions of the similarities, see Martin, supra note 7; Reese, Legislative Jurisdiction, 78 CoLUM L. REV. 1587, 1589 (1978).

74. In personal jurisdiction cases, of course, an unrelated contact not sufficient in itself may be sufficient in conjunction with many others. See Brilmayer, supra note 39.

75. The best example is property, which establishes jurisdiction only if it is the subject matter of the litigation. Rush v. Savchuk, 444 U.S. 320 (1980); Shaffer v. Heitner, 433 U.S. $186,208-09$ (1977). 
poses the contact should be linked to the issue on which the states' laws differ because the state must be using its law on that issue to regulate that contact.

Most modern choice-of-law decisions are consistent with or even implicitly support this interpretation, ${ }^{76}$ but two cases are particularly instructive. In Home Insurance Co. v. Dick 77 the Supreme Court invalidated Texas's attempt to disregard a contractual statute of limitations provision. The contract had been entered into in Mexico, insured against a risk located in Mexico, and was subject to reinsurance agreement by a New York company. The Court declared: "[N]othing in any way relating to the policy sued on, or to the contracts of reinsurance, was ever done or required to be done in Texas." 78 In Watson v. Employers Liability Assurance Corp., ${ }^{79}$ the Court permitted Louisiana to apply its law regarding insurance contracts. Although the contract was negotiated, issued, and delivered outside the forum state, the Watson Court distinguished Dick because the insured-against risk occurred within the forum. The Watson Court observed: "[The Dick court] carefully pointed out that its decision might have been different had activities relating to the contract taken place in Texas upon which the State could properly lay hold as a basis for regulation." 80 Taken together, the Watson and Dick opinions support the requirement of a regulatory connection between the in-state contacts and the rule that the state wishes to apply.

Although the Hague plurality and dissenting opinions skirted the issue of the proper method for assessing the constitutional significance of contacts, they appear consistent with a requirement of a regulatory link. The dissenting opinion clearly had something of this sort in mind when it objected that "[t]he substantive issue here is solely one of compensation, and whether the compensation provided by this policy is increased or not will have no relation to the State's employment policies." 81 Some language in the plurality opinion

76. See, e.g., Clay v. Sun Ins. Office, Ltd., 377 U.S. 179, 183 (1964) (Florida had ample contacts with the transaction where insured-against risk occurred there); Carroll v. Lanza, 349 U.S. 408, 413 (1955) (state where tort occurs certainly has a concern in the problems following in the wake of injury); Alaska Packers Assn. v. Industrial Accident Commn., 294 U.S. 532, $542-43$ (1935) (California had legitimate public interest in controlling and regulating California employer-employee relationship by applying its workmen's compensation law).

77. 281 U.S. 397 (1930).

78. 281 U.S. at 408. See 281 U.S. at 408 n.5.

79. 348 U.S. 66 (1954).

80. 348 U.S. at 71 (emphasis added).

81. 101 S. Ct. at 654 (Powell, J., dissenting). See 101 S. Ct. at 653 (Powell, J., dissenting) (Even if an insurer does business in the forum, "[t]he forum state has no interest in regulating that conduct of the insurer unrelated to property, persons or contracts executed within the forum State."). 
suggests that the plurality also believed that Minnesota's right to regulate its employment relationships justified application of Minnesota's stacking law. ${ }^{82}$ Moreover, if the Court did not have in mind some sort of requirement of a relationship between the contact and the issue, then the contacts that it pointed to would support application of forum law on any issue equally strongly. Since the modern view is that the relevance of contacts is a function of the issues involved, ${ }^{83}$ it seems reasonable to assume that the plurality did not mean to grant Minnesota employment talismanic significance for all legal issues. Some sort of link between this issue and the employment contact must, therefore, be shown.

\section{B. As Between State and Federal Law}

Two types of regulatory connections may link a forum contact with the rule that the state seeks to apply - formal substantive relevance and informal policy relevance. For a contact to be formally relevant to a rule, the rule itself must be phrased in terms of the contact. Returning to an earlier example, the reason that we know that a workmen's compensation rule regulates employment is that it is phrased in terms of the consequences of employment. These rules also regulate accidents since they prescribe the consequences of having an accident in the course of one's employment. Similarly, speed limits are phrased in terms of driving at different speeds. Thus both employment and accidents are formally relevant to workmen's compensation, and the driving that led up to an accident is formally relevant to the speed limit rule. But employment is not formally relevant to the speed limit rule, and Minnesota employment of the deceased does not make application of the Minnesota speed limit presumptively proper. By asking what facts a rule explicitly addresses, one can make an initial determination whether the rule regulates the in-state contact.

Formal substantive relevance is not the only way that a forum contact can create a legitimate interest - informal policy relevance

82. $101 \mathrm{~S}$. Ct. at 641 ("Minnesota's workforce is surely affected by the level of protection the State extends to it, either directly or indirectly. Vindication of the rights of the estate of a Minnesota employee, therefore, is an important state concern.").

83. The Second Restatement shares with interest analysis the principle that the policies underlying the competing rules are pertinent to deciding the relevance of forum contacts. RESTATEMENT (SECOND) OF CoNFLICT OF LAWS $\$ \$ 6(2)(b)$, (c), (e) (1971). See Leflar, supra note 55 , at 1587 (fourth factor in choice-of-law process is advancement of forum's governmental interests). The plurality's casual citation to workmen's compensation cases suggests that it may think that if a contact is relevant to one issue, such as workmen's compensation, then it is relevant for all. See note 71 supra. But this is out of line with all modern theory, and conflicts with its apparent approval of policy-oriented approaches. 
may also suffice. Formal substantive relevance is too stringent a test to capture all of the activities that the legislature or common-law judge meant to regulate by adopting a rule. Rules have traditionally been interpreted in light of their underlying policies as well as their explicit language because they may be addressed to problems not specifically mentioned. For instance, a consumer protection statute might be motivated by concern about overreaching by merchants. To further the statute's policy, the state might refuse to enforce any disclaimers of consumer warranties because it presumes that merchants procure these disclaimers through overreaching. Although the state seeks to regulate overreaching, it does not require that the complaining party prove overreaching in each case. Even though not explicitly mentioned in the text of the rule, overreaching occurring within the state would constitute a constitutionally relevant contact because it informs the statute's proper interpretation in domestic cases.

A third type of relevance that does not supply a regulatory justification greatly complicates the problem of assessing formal substantive relevance and informal policy relevance. The forum contact may have only evidentiary rather than regulatory significance. The state may not be attempting to regulate the occurrence, but only using it as evidence that the regulated events took place. For example, the defendant's legal ownership and possession of an automobile may be probative of whether he was the driver of an automobile in a hit-and-run accident. But the state does not apply its hit-and-run statutes to regulate automobile ownership because ownership itself is not important. ${ }^{84}$ Hit-and-run rules regulate driving, having accidents, and leaving the scene; these would be significant contacts but ownership, per se, would not. Whether formally or informally related to the rule, a constitutionally relevant contact must possess regulatory, not merely evidentiary, value.

To ascertain whether a rule regulates the in-state contact, one consults its language and underlying policies. But the existence of a regulatory nexus, and hence, a legitimate interest cannot be mechanically determined. There is no list of intrinsically significant contacts to consult, especially with respect to informal policy relevance. Because the number and scope of a rule's underlying policies are debatable, disagreements about the constitutional status of certain contacts are inevitable. This causes a serious problem. Since a state court has wide latitude to state a rule's underlying policies, it might

84. Of course, ownership, per se, could be important if other rules, such as a vicarious liability rule, were at stake. 
rely upon dubious domestic policies to satisfy itself that constitutional requirements are met.

Even if courts restrict their regulatory justifications to domestic policies, states nevertheless apparently possess methods for evading the federal constitutional limits on choice of law. The assessment of informal policy involves the interpretation of state statutes and case law, and so is a matter of state law. Each state may define its own substantive goals, including both formal criteria for application of a rule and the rule's implicit regulatory purposes. In Hague, for instance, the Minnesota Supreme Court could assert that, as a matter of state law, the stacking rule regulates employment. And because federal courts generally lack authority to reverse a state's interpretation of its own law, ${ }^{85}$ this proclamation arguably should be dispositive. State courts possess seemingly unreviewable discretion that they can use to evade the constitutional issue. Instead of alluding to an explicit multistate policy the state merely rephrases the policy in domestic regulatory terms. It need not say that Minnesota wishes to apply its law where the deceased was employed in the state; it just discerns an intent to regulate employment through insurance stacking. By thus "creatively" interpreting a rule's policies, state courts would be able to attribute constitutional significance to in-state contacts, and effectively decide for themselves the scope of constitutional limits on choice of law.

\section{Expressions of Domestic Interest}

Where the state has asserted explicit multistate policies, the proper Supreme Court response is relatively simple: ignore them. Multistate policies are not as easily disregarded, however, when disguised as domestic regulatory justifications because it is harder to identify them. Yet a policy so disguised is no less objectionable on that score. It is still a purely multistate policy: because it serves no purpose in purely domestic cases, its relevance is conditioned upon the presence of multistate variables. To insure that a state court does not manipulate its statement of a rule's domestic policies to enable its action to survive constitutional scrutiny, spurious regulatory justifications must be discounted. There are two possible ways to accomplish this goal.

First, the Court could evaluate the supposed regulation empiri-

85. See Martin v. Hunter's Lessee, 14 U.S. (1 Wheat.) 304 (1816). But cf. Hicks v. Oklahoma, 447 U.S. 343 (1980) (denial of state-created right to a jury trial not merely a matter of state procedural law; arguably an instance of "liberty or property" clause exception discussed in text at notes $92-95$ infra). 
cally, asking whether the rule in question actually regulates the contact effectively. Such an inquiry into the substantive reasonableness of the purported regulatory justification is reminiscent of the oldfashioned substantive due process. In its effort to uncover pretense, the Court would risk invalidating bona fide attempts to regulate instate activities because, in the Court's view, the regulatory means are ineffectual or misconceived. Furthermore, if it invalidates existing domestic policies as applied to choice-of-law cases, then it must either invalidate their use in domestic cases also, or have different tests for efficacy in the domestic and choice-of-law contexts. The Court should be as reluctant to intrude on a state's legitimate efforts to formulate its own law ${ }^{86}$ as to defer to any and all hypothesized justifications. 87

The alternative to substantive review of asserted regulatory justifications is insistence that some objective manifestation in the state's internal law support the asserted policy. Under this approach, federal law would not tell a state what domestic policies it may adopt; federal law would merely require that the state itself has demonstrably chosen them. Thus, instead of challenging the efficacy of a regulatory policy, the Supreme Court need only require proof of its existence. This second standard of federal review may seem novel in the conflicts context, but it finds support in three analogous areas of constitutional litigation: property clause, contract clause, and adequate state procedural ground cases.

As in the choice-of-law setting, constitutional limits in property and contract clause cases protect interests defined by state law. The Constitution's due process and contract clauses prevent the states from "depriving" individuals of property ${ }^{88}$ and "impairing" the obligation of contracts. ${ }^{89}$ These clauses do not themselves create prop-

86. In "fundamental rights" cases where the Court has applied strict scrutiny, it has empirically evaluated the asserted justification. See, e.g., Shapiro v. Thompson, 394 U.S. 618, 63338 (1969) (investigating empirical basis for argument that waiting period for welfare benefits facilitates budget predictability).

87. The comparison between due process low-level scrutiny and the standard of review proposed in this Article is discussed in the text at notes 108-09 infra. The "rational basis" test would allow virtually any regulatory justification to be hypothesized after the fact. See, e.g., McGowan v. Maryland, 366 U.S. 420, 426 (1961) ("A statutory discrimination will not be set aside if any state of facts reasonably may be conceived to justify it."). $C f$. Schweiker v. Wilson, 101 S. Ct. 1074, 1088 (1981) (Powell, J., dissenting) ("Court should receive with some skepticism post hoc hypotheses about legislative purpose").

88. U.S. CoNST. amend. XIV, \& 1 ("nor shall any State deprive any person of life, liberty, or property without due process of law").

89. U.S. CoNST. art. I, $\S 10$, cl. 1 ("No State shall . . . pass any . . . Law impairing the Obligation of Contracts"). 
erty and contract rights;" io instead, they "[throw] a federal constitutional shield around property interests initially created by state law."91 For this reason, the state courts' conceded authority to shape substantive law apparently would enable them to defeat constitutional claims. State courts might manipulate state legal doctrine to deny that a property interest had ever been created 92 or a contract formed. 93 This, of course, the Court has not permitted. "[I]n order that the constitution may not become a dead letter"94 the Court has assumed a limited federal power to review state law issues. It does not determine what state law ought to be, but only what it has been all along - to meet a constitutional challenge, state-created definitions must find a "fair and substantial basis" in existing state law.95

A related federal limitation on state lawmaking power involves the adequacy of alternative state procedural grounds in cases that involve federal issues. Ordinarily, the Supreme Court will not decide the federal issues in a case if an adequate and independent state procedural ground supports the decision below. 96 There remains, however, a possibility that state courts will adjust procedural doctrine solely to escape constitutional commands. In fact, many of these independent state ground cases involved apparently hostile

90. See, e.g., Bishop v. Wood, 426 U.S. 341 (1976); Board of Regents v. Roth, 408 U.S. 564 (1972); Demorest v. City Bank Farmer's Trust Co., 321 U.S. 36 (1944); Indiana ex rel. Anderson v. Brand, 303 U.S. 95 (1938); Hale v. State Board, 302 U.S. 95 (1937); Broad River Power Co. v. South Carolina ex rel. Daniel, 281 U.S. 537 (1930).

91. Monaghan, of "Liberty" and "Property", 62 CoRNell L. Rev. 405, 435 (1977). See Board of Regents v. Roth, 408 U.S. 564, 577 (1972) ("Property interests, of course, are not created by the Constitution. Rather, they are created and their dimensions are defined by existing rules or understandings that stem from an independent source such as state law.").

92. See, e.g., Indiana ex rel. Anderson v. Brand, 303 U.S. 95 (1938). See generally Hale, The Supreme Court and the Contracts Clause, 57 HARv. L. REv. 512, 621, 824 (1944).

93. See, e.g., Bishop v. Wood, 426 U.S. 341 (1976).

94. Indiana ex rel. Anderson v. Brand, 303 U.S. 95, 98 (1938). See Monaghan, supra note 91 , at 435 . Novelty is suspect because novel state grounds may be motivated by the desire to defeat the federal claim. See Enterprise Irrigation Dist. v. Farmers Mut. Canal Co., 243 U.S. 157, 164 (1917); Terre Haute \& I. R.R. v. Indiana ex rel. Ketchum, 194 U.S. 579, 589 (1904) (to allow untenable construction "would open an easy method of avoiding the jurisdiction of this court").

95. Demorest v. City Bank Farmer's Trust Co., 321 U.S. 36, 42 (1944); Broad River Power Co. v. South Carolina ex rel. Daniel, 281 U.S. 537, 540 (1930).

96. See Cardinale v. Louisiana, 394 U.S. 437, 439 (1969); Herndon v. Georgia, 295 U.S. 441, 443 (1935). See generally P. BATOR, P. Mishkin, D. ShAPIRo \& H. WeChSLER, supra note 51, at 526; Hill, The Inadequate State Ground, 65 ColuM. L. REv. 943 (1965); Sandalow, Henry v. Mississippi and the Adequate State Ground: Proposals For a Revised Doctrine, 1965 Sup. CT. REv. 187 [hereinafter cited as Sandalow]; Note, The Untenable Nonfederal Ground in the Supreme Court, 74 Harv. L. Rev. 1375 (1961). State procedural requirements that do not satisfy due process requirements, however, clearly cannot bar Supreme Court review. See Reece v. Georgia, 350 U.S. 85 (1955); Brinkerhoff-Faris Trust \& Sav. Co. v. Hill, 281 U.S. 673 (1930); Saunders v. Shaw, 244 U.S. 317 (1917). 
Southern courts deciding constitutional issues in civil rights cases. ${ }^{97}$ For obvious reasons, the Court has not been inclined to accuse states of evading constitutional requirements and has not framed its test in terms of evasion: "Inquiry into the intent of a state court is sufficiently hazardous and the likely results of such doubtful utility that it ought not to be undertaken."98 But the Court has not ignored the possibility. Instead, it has tried to use objectively measurable criteria. ${ }^{99}$ Thus, if the Court finds that the state procedural ground is novel, ${ }^{100}$ unsubstantial, ${ }^{101}$ or "not strictly or regularly followed," 102 it may hear the constitutional issues. In asking whether there is adequate support in prior case law, ${ }^{103}$ the Court acts comparably to a federal court sitting in diversity and deciding an issue of state law. ${ }^{104}$ It decides not what state law ought to be, but rather what the state's precedents indicate that the law presently is. ${ }^{105}$

97. Wright v. Georgia, 373 U.S. 284 (1963); NAACP v. Alabama ex rel. Patterson, 357 U.S. 449 (1958). Cf. Demorest v. City Bank Farmer's Trust Co., 321 U.S. 36, 49 (1944) (Doug. las, J., concurring); Fox River Co. v. Railroad Commn., 274 U.S. 651,655 (1926) (where state law has not been manipulated to evade federal right, state decision will stand). Henry v. Mississippi, 379 U.S. 443 (1965), also required that a state procedural rule serve a "legitimate state interest." Other cases have not similarly scrutinized procedural rules, and this Article does not rely on that part of the Henry holding. But see Michigan v. Tyler, 436 U.S. 499, 512 n.7 (1978) ("Failure to present a federal question in conformance with state procedure constitutes an adequate and independent ground of decision barring review in this Court, so long as the State has a legitimate interest in enforcing its procedural rule."). It is interesting, however, to note how much this part of the Henry holding resembles the possibility, rejected here, that the Court should analyze purported justifications in terms of whether they constitute an empirically effective regulatory scheme. See text at note 86 supra.

98. Sandalow, supra note 96 , at 219. "A purported state ground is not independent and adequate. . . where the circumstances give rise to an inference that the state court is guilty of an evasion." Williams v. Georgia, 349 U.S. 375, 399 (1955) (Clark, J., dissenting). But "[t]his charge upon the integrity of a State Supreme Court is so serious that this Court has restricted such findings to cases where the state court decision lacked 'fair support' in the state law." 349 U.S. at 399 n.3 (Clark, J., dissenting).

99. See Sandalow, supra note 96 , at 221 .

100. NAACP y. Alabama ex rel. Patterson, 357 U.S. 449, 457-58 (1958) ("Novelty in procedural requirements cannot be permitted to thwart review in this Court applied for by those who, in justified reliance upon prior decisions, seek vindication in state courts of their federal constitutional rights."). See Missouri ex rel. Mo. Ins. Co. v. Gehner, 281 U.S. 313, 320 (1930).

101. Lawrence v. State Tax Commn., 286 U.S. 276, 282 (1932) ("Even though the claimed constitutional protection be denied on non-federal grounds, it is the province of this Court to inquire whether the decision of the state court rests upon a fair or substantial basis. If unsubstantial, constitutional obligations may not thus be avoided.").

102. Barr v. City of Columbia, 378 U.S. 146, 149 (1964).

103. See Note, supra note 96, at 1385.

104. Cf. Note, No Evidence to Support a Conviction - The Supreme Court's Decisions in Thompson v. City of Louisville and Garner v. Louisiana, 110 U. PA. L. Rev. 1137, 1143 (1962) (contrasting the Federal court's function when it sits in diversity where it decides what state law to apply with its role when reviewing state court decision).

105. The reason for the requirement is explained in Sandalow, supra note 96, at 221: When a state ground of decision is supported by a history of consistent application, even in cases that do not involve a federal claim, it is not likely to have been used by the state court simply as a device to defeat the Court's jurisdiction. 
In one respect, the insistence on evidence of a regulatory connection in the text of the statute, its legislative history, or the case law may be too demanding. The first opportunity for judicial consideration of a substantively relevant fact may arise, by coincidence, in a multistate dispute. This is particularly likely to occur where the state court has had few opportunities to construe the statute. A requirement of a prior expression of the regulatory interest ties the court's hands, and impedes the normal processes of statutory construction. One could argue that this coincidence is so unlikely, and the need for safeguards so great, that this cost must be borne. ${ }^{106} \mathrm{But}$ a more attractive solution is to allow the state court to construe the domestic statute, and then utilize those factors that it has worked into the substance of the legal issue as significant contacts for choice-of-law purposes. When an arguable new construction of the state statute presents itself, the Supreme Court should remand the case to the

This is just one instance of a general phenomenon: reducing the latitude for prejudice by tying the results of one decision to other decisions in which such prejudice is absent and the rewards for competent decision making are substantial. To put it another way, prejudice is restricted by making invidious criteria irrelevant and requiring the same rule to be applied in one situation as in the other. Usually, this means requiring similar treatment of favored and disfavored classes of individuals. See, e.g., J. ELY, supra note 9, at 83-85 (outlining theory of "virtual representation" underlying the privileges and immunities clause). But "virtual representation" also applies to cases. In the present context, multistate cases are tied to domestic cases, for in the latter, the state's policy decisions can be assumed to be sound. In the contracts, property, and state procedural ground contexts, cases with constitutional objections are tied, similarly, to cases in which there are none.

Another context in which the tying phenomenon occurs is stare decisis and neutral principles. General lawmaking power is tied to the decision of concrete cases, each function restricting the other. The potential for biased resolution of particular cases (because, for instance, of prejudice against particular litigants) is checked by the fact that the resolution will affect future cases. See A. Cox, The Role of the Supreme Court in American Government 108-09 (1976). The case-deciding functions provide reciprocal safeguards against irresponsible formulation of legal rules, since the rule must be applied to the case at hand. This last fact underlies some of the objections to making purely prospective judicial decision making. Linkletter v. Walker, 366 U.S. at 225 (Black, J., concurring in part and dissenting in part); Note, Prospective Overruling and Retroactive Application in the Federal Courts, 71 YALE L.J. 907 (1962).

Another example, particularly appropriate for choice-of-law purposes, can be found in the dissenting opinion of Justice Brennan in McGautha v. California, 402 U.S. 183, 261 n.11 (1971). In elaborate dicta, Justice Brennan argued that out-of-staters would be adequately protected in abstention cases only where the resulting interpretation of state law would have future applications. Diversity jurisdiction seeks to protect outsiders from local prejudice, and the federal court could safely abstain when the state court would be adequately restrained by the implications of its decision for nondiversity cases.

For a discussion of the dangers of ad hoc decision making, see McGautha v. California, 402 U.S. 183, 259, discussing Thompson v. Louisville, 362 U.S. 199 (1960) (Supreme Court resolved dispute through analysis of prior state case law); Garner v. Louisiana, 368 U.S. 157 (1961); P. BATOR, P. MishKIN, D. Shapiro \& H. WeChSLER, supra note 51, at 617-18, 620 ("Doesn't the express announcement of the new construction as generally governing the state in the future itself provide some safeguard?"); Note, supra note 104; Note, The Void-for-Vagueness Doctrine in the Supreme Court, 109 U. PA. L. REV. 67, 80 (1960).

106. See Sandalow, supra note 96, at 221. 
state court for clarification of the substantive law. 107

There are superficial similarities between this requirement of an expression of domestic regulatory interest and a proposal advanced by Professor Gerald Gunther for equal protection challenges. ${ }^{108}$ In both equal protection and conflict-of-laws cases, the danger is that states may try to meet constitutional objections with post hoc rationalizations that have no relation to actual and invidious motivations behind the challenged actions. In a well-known article, Professor Gunther argued that when a state defends a statute from an equal protection challenge, it should be limited to policy justifications that played some part in the statute's enactment. Professor Gunther's equal protection proposal, like this Article's recommended standard of review, seeks to prevent states from arbitrarily inventing policies to save their actions from constitutional attack.

As an equal protection doctrine, the prior articulation requirement has been trenchantly criticized. ${ }^{109}$ Although designed to encourage legislatures to air publicly the policies upon which they are relying, the proposal arguably would have a quite different effect. An articulation requirement would have its greatest effect on statutes of states that do not compile extensive legislative histories and on statutes that seemed innocent of constitutional defects when enacted. The first factor is irrelevant to the law's constitutionality, and the second seems actually to evince validity. Moreover, legislatures are likely to respond to a prior articulation requirement by appending to the legislative record a laundry list of policy considerations. The prophylactic value of such an exercise is unclear. Rationalizations are rationalizations, whether offered at the litigation or the enactment stage. Advancing the deadline for offering those rationalizations merely increases the paperwork necessary to enact a statute.

The contrast with the superficially similar choice-of-law requirement is pronounced. Restricting regulatory justifications to factors significant to the substance of the dispute is not designed to en-

107. Cf. Minnesota v. National Tea Co., 309 U.S. 551 (1940) (remanding to state court for clarification of whether state or federal law was the basis for decision).

108. Gunther, The Supreme Court, 1971 Term - Foreword: In Search of Evolving Doctrine on a Changing Court: $A$ Model for a Newer Equal Protection, 86 HARv. L. REv. 1, 44-46 (1972).

109. See, e.g., J. ELY, supra note 9, at 125-31. Although some cases indicate agreement with the articulation model, see, e.g., Massachusetts Bd. of Retirement v. Murgia, 427 U.S. 307, 314 (1976); Weinberger v. Wissenfeld, 420 U.S. 636, 650 (1975); McGinnis v. Royster, 410 U.S. 263, 270 (1973), for the most part the Court seems to ignore it. See J. ElY, supra note 9, at 125; G. Gunther, Cases AND Materials on Constitutional LAw 96, 216-17 (9th ed. Supp. 1979). Cf. Schweiker v. Wilson, 101 S. Ct. 1074, 1088 (1981) (Powell, J., dissenting) ("the Court should receive with some skepticism post hoc hypotheses about legislative purposes"). 
courage the earlier decision makers publicly to express additional domestic substantive policies. Articulation itself is not the touchstone of constitutionality; independent substantive usefulness is. To the extent that the requirement induces states to air their domestic policies, this arguably would beneficially clarify domestic law and identify the multistate circumstances in which a state would apply its domestic law. ${ }^{110}$ But the real reason for the insistence that contacts serve some domestic substantive function is to limit choice-of-law policy justifications to policies on which the state is entitled to rely. ${ }^{111}$ The statute's domestic ramifications provide real safeguards because they mean that some domestic group will feel the statute's pinch. Without a regulatory nexus requirement, states could conjure up different sets of policies for multistate cases, at no cost to state residents, and solely to evade constitutional limitations.

In both conflict-of-law and equal protection cases, a silent record creates an inference that no one ever found it important to articulate the policy justification now being offered. In equal protection cases, however, there is an innocent explanation: given the record-keeping costs or the statute's apparent constitutional innocence, constitutional rationalization seemed unwarranted. In conflicts cases, in contrast, there are no additional record-keeping costs because states are not asked to create special records solely to meet later constitutional challenges. The fact that a state has not articulated a given policy in domestic cases, and cannot now work it into the substance of the dispute, is highly probative of invalidity. It suggests that the state is relying upon illicit multistate policies that cannot support any legitimate interest because they have no substantive relevance to the issue in question.

\section{The Employment Contact In Hague}

Although the plurality thought three contacts constitutionally rel-

110. In this way, a "regulatory purpose" requirement improves the predictability of confiicts rules because the list of factors triggering application of forum law is limited to those already defined by the state's domestic law.

111. Another distinction between Professor Gunther's approach and mine is that equal protection analysis is primarily concerned with means-end relationships, whereas my standard concerns what constitutes an appropriate end. Only goals that inform policies in domestic cases can be utilized as "ends" in choice-of-law analysis. Certainly any means is legitimate if there is no restriction on what ends are chosen, because the rule could be cited as an end in itself. Ely, Legislative and Administrative Motivation in Constitutional Law, 79 YALE L.J. 1205, 1248 (1970). Equal protection analysis usually involves one of the state's virtually infinite legitimate health or safety goals, and asks whether the means is rationally related to that goal. Choice-of-law analysis cannot use the "rational relationship" test, however, until a legitimate domestic goal is brought to light. The "prior expression of a domestic interest" requirement seeks to discover whether such a legitimate goal exists. 
evant, we are concerned here only with one: Minnesota employment. The employment contact is singled out because the plurality evidently attributed great importance to it, and may have been using it to establish a regulatory justification. ${ }^{12}$ Since it is not clear whether the plurality would agree to limit itself to policies useful in the domestic setting, as this Article suggests, criticism of an alternative interpretation of the plurality opinion will follow the demonstration that the requirement of a domestic substantive policy is not met in Hague.

There are two possible ways to try to establish a domestic substantive connection between Minnesota employment and Minnesota's stacking law. Minnesota might be interested in the employment relationship itself, regardless of the employee's domicile, because the employment occurs in Minnesota and involves a Minnesota employer. In the alternative, Minnesota might argue that anyone who works in Minnesota deserves protection under Minnesota law in his own right. In other words, Hague would be entitled to the benefits of Minnesota citizenship by virtue of membership in the Minnesota workforce. The first rationale suggests that a right to regulate arises from concern over a relationship with a Minnesota employer. The second bases the right to regulate upon an interest in Hague himself.

An initial and obvious problem with both of these is that the supposed interest was supplied by the Supreme Court. Because state policies ideally should be the product of statutory construction or interpretation of common-law rules, it is not clear that the Court should supply a regulatory justification that the state court did not advance. ${ }^{113}$ This is particularly problematic where, as here, the state court had purported to analyze completely all the underlying policies and did not mention the one that the Supreme Court unearthed. But this issue is beside the more interesting point: would Minnesota employment be a sufficient contact if offered by the state court? If there is even a minimal requirement that the purported justification find expression in domestic regulatory policy, the answer is clearly "no."

112. A caveat is in order: the plurality stressed the existence of a "significant aggregation of contacts between the parties and the occurrence, creating state interests." Allstate Ins. Co. v. Hague, $101 \mathrm{~S}$. Ct. 633, 644 (1981) (Stevens, J., concurring) (footnote omitted). It expressed no view as to whether the "employment" or the "doing business" contacts, "either together or separately, would have sufficed to sustain the choice of Minnesota law made by the Minnesota Supreme Court." 101 S. Ct. at 644 n.29 (Stevens, J., concurring).

113. Cf. Minnesota v. Clover Leaf Creamery Co., 101 S. Ct. 715, $731-37$ (1981) (Stevens, J., dissenting) (Supreme Court should not uphold state law that the state court had declared invalid under the fourteenth amendment because it promoted no rational state objective). 
Consider first the theory that Minnesota's stacking rule regulates the employment relationship. As a general matter, secondary sources canvassing the policy considerations favoring stacking do not mention employment. ${ }^{114}$ Likewise, the common-law decisions initiating stacking in various states have not mentioned any policies implicating employment. ${ }^{115}$ More important is Minnesota law spe-

114. Secondary sources have identified the relevant arguments for and against insurance stacking. The issue has usually turned on the court's interpretation of the state's uninsured motorist statute. See generally A. WIDISS, A GUIDE TO UNINSURED MOTORIST CoverAGE \$ 8.6 (1969 \& Supp. 1980); Allen, Uninsured Motorist Coverage in Alabama, 36 ALA. LAw. 535 (1975); Hart, Stacking of Motor Vehicle Insurance Coverage in Missouri: $2 \times$ the Deep Pocket, 35 J. Mo. B. 173 (1979); Neighbor, Pyramiding Uninsured Motorist Coverage - Has Iowa Joined the Majority, 23 DRAKE INS. L. ANN. 746 (1974); Comment, The Invalidity of the "Other Insurance" Provision: A New Majority, 17 S.D. L. REv. 152 (1972); Note, Stacked Recovery Under the Uninsured Motorist Endorsement of the Automobile Liability Policy, 9 VAL. L. REV. 135 (1974); Comment, Stacking of Basic Economic Loss Benefits Under the Minnesota No-Fault Automobile Insurance Act, 5 WM. MrTChell L. Rev. 421 (1979); Annot., 28 A.L.R.3d.551 (1969).

The commentators point to two recurrent rationales for insurance stacking: (1) to provide indemnification for the insured against losses caused by the wrongful conduct of an uninsured motorist; and (2) to allow the insured rather than the insurer to benefit from the premiums that have been paid. See, e.g., Comment, The Invalidity of the "Other Insurance" Provision, supra, at 156; Note, supra, at 144.

The commentators also indicate that those jurisdictions that do not permit the stacking of insurance policies typically interpret their uninsured motorist statutes to afford the same protection that the injured party would have received if the uninsured motorist had carried the minimum insurance. Neighbor, supra; Comment, The Invalidity of the "Other Insurance" Provision, supra, at 160.

It does not appear that any secondary source has argued that employment regulation is relevant to the issue of insurance stacking.

115. The Virginia Supreme Court and the Florida Supreme Court were the first courts to identify a public policy in favor of stacking uninsured motorist insurance. Neither court considered the regulation of employment in reaching their decisions. In Bryant v. State Farm Mut. Ins. Co., 205 Va. 897, 140 S.E.2d 817 (1965), the court struck down an "other insurance" provision that limited the amount that the insurer had to pay. Noting that the uninsured motorist statute was enacted for the benefit of injured persons, the court held that any insurance policy provision that conflicted with the statute was void. $205 \mathrm{Va}$. at 901,140 S.E.2d at 819.

The Florida Supreme Court, in Sellers v. United States Fidelity \& Guar. Co., 185 So. 2d 689 (Fla. 1966), stated that the policy behind the Florida uninsured motorist statute was to compensate the insured for his actual losses. Accordingly, the insured can stack insurance to the extent of his damages. 185 So. 2d at 692. The court did not mention employment. Accord, Markham v. State Farm Mut. Auto Ins. Co., 326 F. Supp. 39 (W.D. Okla. 1971), revd., 464 F.2d 703 (10th Cir. 1972); Safeco Ins. Co. of Am. v. Jones, 286 Ala. 606, 243 So. 2d 736 (1970); Fidelty \& Cas. Co. v. Darrow, 161 Conn. 169, 286 A.2d 288 (1971); State Farm Mut. Auto. Ins. Co. v. Murphy, 226 Ga. 710, 177 S.E.2d 257 (1970); Walton v. State Farm Mut. Auto. Ins. Co., 55 Hawaii 326, 518 P.2d 1399 (1974); Patton v. Safeco Ins. Co. of Am., 148 Ind. App. 548, 267 N.E.2d 859 (1971); Benzer v. Iowa Mut. Tornado Ins. Assn., 216 N.W.2d 385 (Iowa 1974); Clayton v. Alliance Mut. Cas. Co., 212 Kan. 640, 512 P.2d 507 (1973); Meridian Mut. Ins. Co. v. Siddons, 451 S.W.2d 831 (Ky. 1970); Graham v. American Cas. Co., 261 La. 85, 259 So. 2d 22 (1972); Blakeslee v. Farm Bureau Mut. Ins. Co., 388 Mich. 464, 201 N.W.2d 786 (1972); Van Tassel v. Horace Mann Ins. Co., 296 Minn. 181, 207 N.W.2d 348 (1973); Bose v. American Family Mut. Ins. Co., 186 Neb. 209, 181 N.W.2d 839 (1970); Sloan v. Dairyland Ins. Co., 86 N.M. 65, 519 P.2d 301 (1974); Moore v. Hartford Fire Ins. Co. Group, 270 N.C. 532, 155 S.E.2d 128 (1967); Curran v. State Auto Mut. Ins. Co., 25 Ohio St. 2d 33, 266 N.E.2d 566 (1971); Harleysville Mut. Cas. Co. v. Blumling, 429 Pa. 389, 241 A.2d 112 (1968); Pickering v. American Employers Ins. Co., 109 R.I. 143, 282 A.2d 584 (1971); Boyd v. State Farm Mut. 
cifically. An exhaustive computerized search of Minnesota case law uncovered no suggestion that employment and insurance stacking are related.116 Not surprisingly, neither plaintiffs nor defendants have ever found it worthwhile to allege or deny employment in stacking cases; ${ }^{117}$ it is hard to understand how this fact would add

Auto. Ins. Co., 260 S.C. 316, 195 S.E.2d 706 (1973); Westphal v. Amco Ins. Co., 87 S.D. 404, 209 N.W.2d 555 (1973); American Liberty Ins. Co. v. Ranzau, 481 S.W.2d 793 (Tex. 1972).

The only time that the Florida courts have mentioned employment has been when the injured party was involved in an accident in the course of his employment and sought to stack his employer's uninsured motorist policies. The courts limit insurance stacking to situations where a familial relationship exists between the insured and the injured party. Hartford Accident \& Indem. Co. v. Richendollar, 368 So. 2d 603 (Fla. Dist. Ct. App. 1979); Travelers Ins. Co. v. Pac, 337 So. 2d 397 (Fla. Dist. Ct. App. 1976) (per curiam). But see Lezcano v. Leatherby Ins. Co., 372 So. $2 d 214$ (Fla. Dist. Ct. App. 1979) (per curiam); United States Fidelity \& Guar. Co. v. Curry, 371 So. 2d 677 (Fla. Dist. Ct. App. 1979) (per curiam). The focus is on the interest of the injured party and the parties to the insurance contract, not on any generalized employment interest.

A Lexis search of all states produced no cases involving insurance stacking in which the court considered regulation of employment to resolve the stacking issue. The following search was run:

Level 1: insurance w/seg stack! - 1021 cases

Level 2: w/seg employ! or work -741 cases

Level 3: w/seg vehicle or automobile or car -403 cases

Level 4: w/seg uninsured -168 cases

The cases in levels 1,2 , and 3 were randomly scanned. Each case in level 4 was checked.

116. In Van Tassel v. Horace Mann Mut. Ins. Co., 296 Minn. 181, 207 N.W.2d 348 (1973), the Minnesota Supreme Court identified the factors underlying its stacking rule:

[T] he fact that the legislature required an uninsured-motorist provision in all policies, added to the fact that a premium has been collected on each of the policies involved, should result in the policyholder's receiving what he paid for on each policy, up to the full amount of his damages. . . . [T]rue . . such [a] holding results in permissible recovery exceeding what he would have received if the uninsured motorist had been insured for the minimum amount. . . . But if the question must be resolved on the basis of who gets a windfall, it seems more just that the insured who has paid a premium should get all he paid for rather than that the insurer should escape liability for that which it collected a premium.

296 Minn. at 187, 207 N.W.2d at 351-52. The court did not mention employment. Nor have the Minnesota cases subsequent to Van Tassel identified any nexus between employment and the decision to allow or disallow the stacking of insurance benefits. See, e.g., Roepke v. Western Natl. Mut. Ins. Co., 302 N.W.2d 350 (Minn. 1981); Koons v. National Family Ins. Co., 301 N.W.2d 550 (Minn. 1981); Wallace v. Tri-State Ins. Co., 302 N.W.2d 337 (Minn. 1980); Hennekens v. All Nation Ins. Co., 295 N.W.2d 84 (Minn. 1980); Petty v. Allstate Ins. Co., 290 N.W.2d 763 (Minn. 1980); Holman v. All Nations Ins. Co., 288 N.W.2d 244 (Minn. 1980); Haagenson v. National Farmers Union Property \& Cas. Co., 277 N.W.2d 648 (Minn. 1979); Wasche v. Milbank Mut. Ins. Co., 268 N.W.2d 913 (Minn. 1978); Hennen v. St. Paul Mercury Ins. Co., 312 Minn. 131, 250 N.W.2d 840 (1977); National Gen. Ins. Co. v. American Standard Ins. Co., 311 Minn. 415, 249 N.W.2d 453 (1977); Integrity Mut. Ins. Co. v. State Auto \& Cas. Underwriters Ins. Co., 307 Minn. 173, 239 N.W.2d 445 (1976); Taylor v. Great Cent. Ins. Co., 305 Minn. 446, 234 N.W.2d 590 (1975); Pleitgen v. Farmers Ins. Exch., 296 Minn. 191, 207 N.W.2d 535 (1973).

117. The only cases that arguably give rise to an employer's interest in allowing insurance stacking are those cases that allow the workmen's compensation carrier to set off the amounts paid under the uninsured motorist policies. See Boehler v. Insurance Co., 290 F. Supp. 867 (E.D. Ark. 1968) (Arkansas Workmen's Compensation law allows employer's carrier to set off the amount paid under the uninsured motorist policy); Board of Regents of the Univ. Sys. v. Oelke, 120 Ga. App. 667, 172 S.E.2d 183 (1969), revd., 266 Ga. 310, 174 S.E.2d 920 (1970) (Court of Appeals allowed set-off by workmen's compensation carrier but was reversed by the 
anything to the merits of the case. It is similarly difficult to comprehend how a prospective domestic construction of the stacking rule might take employment into account. In substantive terms, employment is utterly superfluous. In fact, in Hague the plaintiff did not claim that her husband's employment was relevant to the merits; employment was alleged only for choice-of-law purposes. ${ }^{118}$

Minnesota can hardly claim, therefore, that its stacking rule regulates the employment relationship. The second explanation, that Minnesota considers members of its work force entitled to all of the advantages that it bestows upon citizens, is equally untenable. One could argue that Minnesota "cares" about employees in the way that it "cares" about residents. This is certainly a plausible interpretation of the plurality's language:

While employment status may implicate a state.interest less substantial than does resident status, that interest is nevertheless important. The State of employment has police power responsibilities towards the nonresident employee that are analogous, if somewhat less profound, than towards residents. Thus, such employees use state services and amenities and may call upon state facilities in appropriate circumstances. ${ }^{119}$ But even if one grants that application of forum law should, like state services, be limited to residents, it is unclear.why in-state employment would entitle a claimant to the benefits of Minnesota law. It seems hardly more persuasive than bestowing those benefits upon all persons who had once resided in the state, or persons who owned

Georgia Supreme Court). Cf. Hackman v. American Mut. Liab. Ins. Co., 110 N.H. 87, 261 A.2d 433 (1970) (court approved set-off but did not resolve whether the workmen's compensation carrier or the uninsured motorist carrier should receive the subrogation rights). But see Travelers Ins. Co. v. National Farmers Union Property \& Cas. Co., 252 Ark. 624, 480 S.W.2d 585 (1972) (Arkansas workmen's compensation law does not allow set-off). These cases are irrelevant to our discussion because the accident giving rise to a workmen's compensation claim must occur during the course of employment. The employment interests are triggered by this fact, not by the issue of insurance stacking.

Moreover, the Minnesota Supreme Court has expressly ruled against such a set off by the workmen's compensation carrier. Janzen v. Land O'Lakes, Inc., 278 N.W.2d 67, 69 (Minn. 1979), held that although the workmen's compensation law gives the compensation carrier a right to be subrogated to the rights of the injured party against third-party tortfeasors, an uninsured motorist liability carrier is not a tortfeasor. For further discussion on this topic, see A. Widiss, supra note 114, \$2.67; Note, Uninsured Motorist Insurance Offset for Workmen's Compensation Benefits, 26 ARK. L. REv. 570 (1973); Comment, Uninsured Motorist Coverage in Louisiana, 24 Loy. L. Rev. 85, 108-09 (1978); Note, Workmen's Compensation - Subrogation - Liability of Uninsured Motorist Carrier, 22 MERCER L. REv. 621 (1971).

118. Cf. Brilmayer, supra note 39, at 104-05 (rejecting as a basis for personal jurisdiction property that is alleged only for jurisdictional purposes). While it may be sufficient in the personal jurisdiction context to establish relevance to the case in general, in choice of law the contact must be substantively relevant to the issue on which the state's laws differ. In Hague, employment was irrelevant to any of the legal issues. But even if there were some substantive purpose for alleging employment, this would be insufficient if that purpose were unrelated to the stacking issue in the case.

119. $101 \mathrm{~S}$. Ct. at $640-41$. 
real property there, or persons with Minnesota relatives. On what theory would employees evoke such solicitude?

A canvass of Minnesota's social welfare statutes demonstrates that the plurality's analogy between employees and residents is unfounded. Eligibility for Minnesota State Assistance is, by a general provision, conditioned upon residence, not employment in the state. ${ }^{120}$ Many other social benefit statutes also afford preferential treatment based upon residence. ${ }^{121}$ The only benefits that refer to employment are those that the state provides to employees in the employment context. ${ }^{122}$ The state's "police power responsibilities" toward employees are, indeed, "somewhat less profound, than towards residents." 123 When Minnesota foots the bill, it cares very little about its work force. The solicitude that the Supreme Court imputed to Minnesota seems peculiar to choice-of-law cases in which such solicitude rationalizes the application of Minnesota law.

The obvious lack of any domestic policy foundation for drawing a regulatory connection between employment and the stacking rule suggests that the plurality must have had another sort of justification in mind. Its failure to explain how employment supports application of the insurance stacking rule is frustrating. At one point the plurality contended that Minnesota had an interest in applying its law because affording compensation to the estate of a Minnesota employee "surely affected"124 its work force. Perhaps, then, the thrust of its reasoning was that the existence of some empirical consequences in the state should be enough, regardless of whether the empirical consequences are significant in light of existing domestic policy.

In view of the arguments already offered, it is not clear why a contact should count when the state has accorded it no legal relevance and the sole purpose for alleging it is to justify application of forum law. But even if a domestic relevance test is not adopted, an actual effects test is unacceptable in theory and as applied. As ap-

120. See MinN. Stat. $\S \S 256.455-.456$ (1974). This includes aid to the needy, see MiNN. STAT. \$ 256B.06; tuition subsidies, loans, and scholarships at the state university, see MiNN. STAT. §§ 136A.121, .161(3) (1974); and soldiers' welfare funds, see MINN. STAT. § 197.03 (1974).

121. See, e.g., MiNN. STAT. ANN. \$128A.07 (West 1979) (resident preference for admission to state schools for the deaf); MINN. STAT. \$\$ 248.03-.04 (1974) (residents given preferencial treatment after graduating from state schools for the deaf); MINN. STAT. $\$ \$ 246.23$, 256D.18 (1974) (residents given preferential treatment at mental institutions).

122. For instance, employers must make health plans available to their employees. See MinN. Stat. ANN. § 62E (West Supp. 1980); MinN. STAT. ANN. § 254.A12 (West Supp. 1980) (county may provide drug abuse service to employers for their employees).

123. Allstate Ins. Co. v. Hague, 101 S. Ct. 633, 640 (1981) (plurality opinion).

124. $101 \mathrm{~S}$. Ct. at 641 . 
plied, the test does not require any empirical showing of substantial impact on the Minnesota work force. Yet most members of the work force are likely to be indifferent to the Hague rule because they will be protected by virtue of Minnesota residence, Minnesota delivery of the insurance policy, or Minnesota locus of the accident. It cannot, therefore, be taken for granted that there is an impact on the work force in general. ${ }^{125}$ Unwillingness to require empirical support is apt if the state has an actual domestic regulatory scheme because the Court should be reluctant to second guess a bona fide regulatory judgment. But where the state has no general domestic policy of regulating employment through insurance stacking, the Court would not be second guessing a state's decision about a domestic issue admittedly within the state's lawmaking competence. It would merely be concluding, rather reasonably, that a state must show something other than a naked inclination to apply forum law on any pretext.

In theory, an effects test is inadequate because it imposes virtually no limits at all. As Hague illustrates, it is almost always possible to hypothesize in-state consequences. Insurance stacking just as "surely affects" Minnesota interests in cases where the plaintiff's lawyer is licensed in Minnesota and is working for a contingent fee. Or in Hague, the plurality could have cited the Minnesota residence of the plaintiff's new husband as establishing an "effect." Since all contacts seem equally sufficient to satisfy a test based on "actual effect," then the requirement that they be "significant contacts, creating interests," is vacuous. The plurality may have accepted employment as a significant contact simply because it had no idea what it was looking for.

\section{CONCLUSION}

The requirement of a domestic regulatory connection developed in this Article both resembles and departs from the traditional governmental interest methodology. One difference is that this approach recognizes a wider range of constitutionally significant contacts. Although Brainerd Currie sometimes argued that traditional connecting factors were irrelevant to evaluation of interests, ${ }^{126}$

125. If an impact on the work force in general is not required, and impact on a specific member of the work force is enough, then the argument merely restates the conclusion: Hague's employment status is significant because stacking affects a member of the Minnesota work force.

126. See B. CuRrIe, supra note 10, at 116 (residence of parties important in married women's contracting cases, but not place of contracting). See generally id. at 77-127 (explaining the situations in which states have interests in such cases). Currie also argued that application of Arizona law in Grant v. McAuliffe, 41 Cal. 2d 859, 264 P.2d 944 (1953), on the "place of 
the restrictive aspects of his constitutional theory are inherently implausible and find no support in the cases. ${ }^{127}$ More importantly, this Article goes beyond the existing governmental interest literature. Although interest analysts have used state policies to define interests, they never came to grips with the theoretical difficulties that such reliance creates. Uncritical deference to a state's multistate policies, whether explicitly stated or disguised as domestic justifications, emasculates constitutional standards.

The similarities, however, are striking. Both approaches reject a mechanical search for contacts possessing talismanic significance, ${ }^{128}$ and emphasize instead the litigation context in which the issues arise. In particular, both recognize that courts must assess a contact's constitutional value in light of the underlying policies of the rule to be applied. Furthermore, although interest analysts have not noticed the problems in defining the role of state and federal law, they might agree with this Article's proposed solution once the question is squarely posed. Thus Part I's rejection of conflict-of-law policies may be implicit in what Currie had in mind all along. ${ }^{129}$ And Part II's requirement that a state's domestic policies have objective support serves some of the same purposes as the recent insistence that legitimate interests be "real" rather than speculative. ${ }^{130}$

The theory of legitimate interests presented here addresses only a small subset of constitutional choice-of-law issues. It is sometimes

wrong" theory would be a denial of due process. B. CuRRIe, supra note 10, at 162-63; id. at 583 (when Court finally becomes enlightened, it will hold that traditional rules violate the equal protection clause).

127. Hague itself seemed to proceed on the assumption that traditional rules supplied adequate constitutional basis for application of forum law. It cited a number of older cases that had used the "place of wrong" and "place of making" tests. $101 \mathrm{~S}$. Ct. at $638 \mathrm{n.11}$ (plurality opinion).

One other indication that interest analysis is more restrictive than the constitutional test can be found in Day \& Zimmermann, Inc. v. Challoner, 423 U.S. 3 (1975). A lower federal court sitting in diversity had declined to follow the state's First Restatement approach on the theory that on the facts the place of wrong had "no interest." The Supreme Court reversed, citing Klaxon Co. v. Stentor Elec. Mfg. Co., 313 U.S. 487 (1941). If the constitutional "interest" test were the same as Currie's, the lower court would have been right, albeit for the wrong reason. Day \& Zimmermann did not address the constitutional question. Yet the failure to raise or discuss the question suggests that the parties and the Court saw no constilutional problems in a state using the "place of wrong" rule. Certainly, if interest analysis were a constitutional requirement, the case was wrongly resolved.

128. It should be noted that even the First Restatement did not make one factor talismanic for all issues. It used different contacts for contract, tort, and procedural issues, for instance.

129. See note 59 supra.

130. See Sedler, The Governmental Interest Approach to Choice of Law: An Analysis and a Reformulation, 25 UCLA L. REv. 181, 221 (1977) (asking whether there is a "real" interest as opposed to a hypothetical or a possible interest). The test Professor Sedler urges is, however, quite different from mine. See also B. CuRRIE, supra note 10, at 277 (Supreme Court may ask whether policy has any demonstrable existence). 
maintained that a state can constitutionally apply its law whenever it has a legitimate interest. ${ }^{131}$ My argument that a legitimate interest gives a state a prima facie claim to apply its law is less ambitious, leaving open the possibility that one state's interests may constitutionally outweigh another's. ${ }^{132}$ Additionally, even if a state has no legitimate interest, it may still be necessary to ascertain that an alternative jurisdiction's rule would be constitutionally preferable. ${ }^{133} \mathrm{Fi}-$ nally, this Article's definition of legitimate interests primarily considers limitations based upon state sovereignty. Other constitutional limits are created by due process fairness concerns, ${ }^{134}$ and by the equal protection ${ }^{135}$ and privileges and immunities ${ }^{136}$ clauses.

Despite its admitted limitations, this theory of legitimate interests is a needed first step. Unfortunately, the Hague plurality failed to provide standards for determining when contacts are significant and interests legitimate. Unless "legitimate interests" is either to remain a purely question-begging formulation of the constitutional conclusion, or else to disintegrate into a carte blanche for the states to do exactly as they please, some judicial clarification is in order.

131. B. CURRIE, supra note 10, at 189.

132. Application of the law of an alternative jurisdiction may not violate state sovereignty but it may run afoul of other constitutional values. See notes 134-36 infra. In this situation the Court faces a difficult balancing question because, no matter which jurisdiction is allowed to apply its law, at least one constitutional concern will suffer. This problem will be the subject of a future article.

133. Compare Brilmayer, supra note 39, at 110 (discussing "reciprocal contacts"), with Currie's position, illustrated in note 59 supra, that such a constitutional determination is unnecessary.

134. The cases have sought to protect the litigants from unfair surprise. See Allstate Ins. Co. v. Hague, $101 \mathrm{~S}$. Ct. at $648 \mathrm{n} .16$ (Stevens, J., concurring). Thus, it must be asked whether the in-state contacts can be fairly attributed to the adverse party. $C f$. Brilmayer, supra note 39 , at 91 (discussing the analogous problems of causation and foreseeability in the adjudicative jurisdiction context).

135. U.S. Const. amend. XIV, \& 1. See note 64 supra.

136. U.S. ConsT. art. IV, § 2, cl. 1. See note 64 supra. 